\title{
Of which we cannot speak: philosophy and the humanities
}

\section{Citation}

Rodowick, D. N.. 2011. Of which we cannot speak: philosophy and the humanities. Zeitschrift für Medien- und Kulturforschung 2:9-22.

\section{Permanent link}

http://nrs.harvard.edu/urn-3:HUL.InstRepos:5344186

\section{Terms of Use}

This article was downloaded from Harvard University's DASH repository, and is made available under the terms and conditions applicable to Open Access Policy Articles, as set forth at http:// nrs.harvard.edu/urn-3:HUL.InstRepos:dash.current.terms-of-use\#OAP

\section{Share Your Story}

The Harvard community has made this article openly available.

Please share how this access benefits you. Submit a story.

\section{Accessibility}




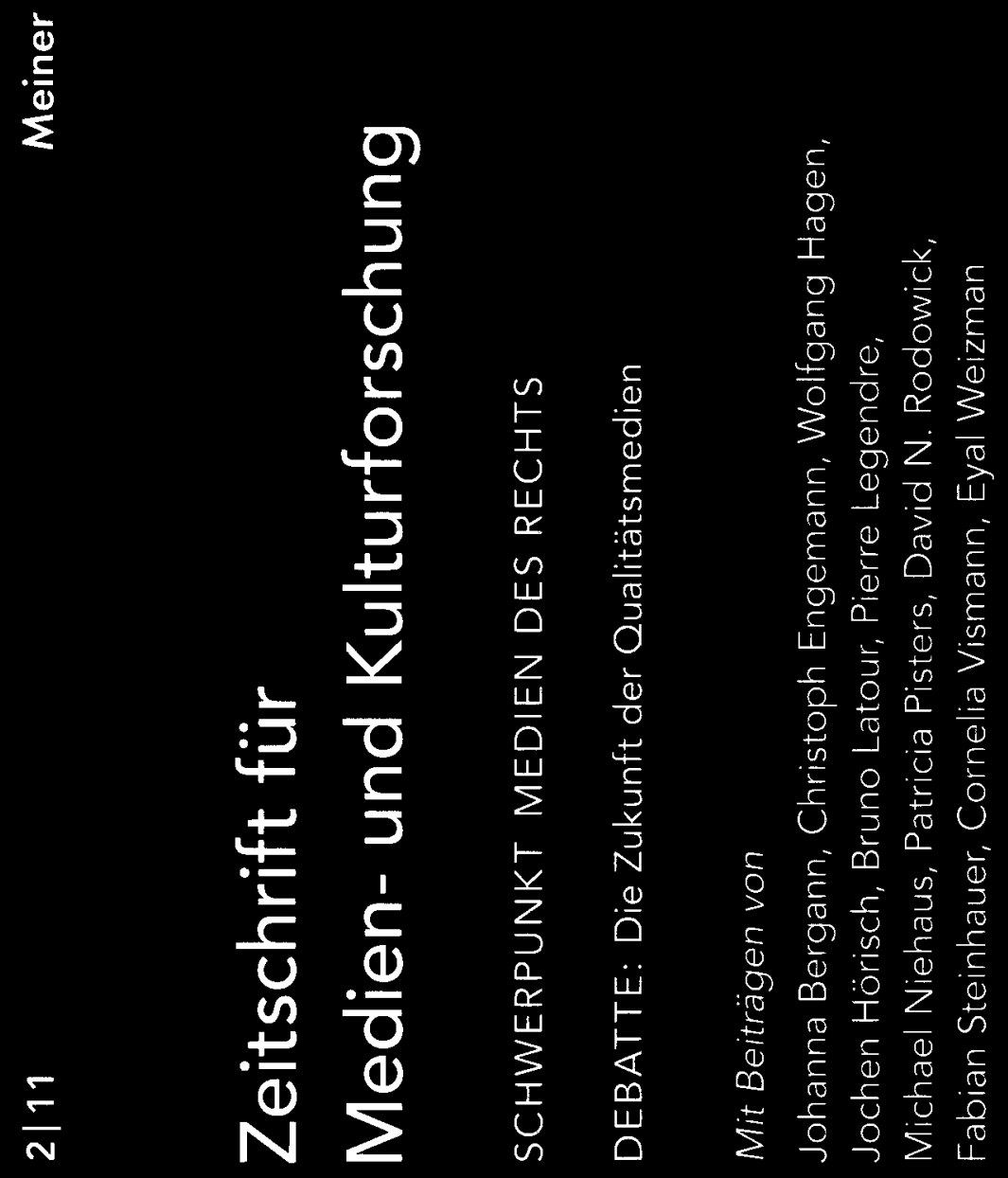



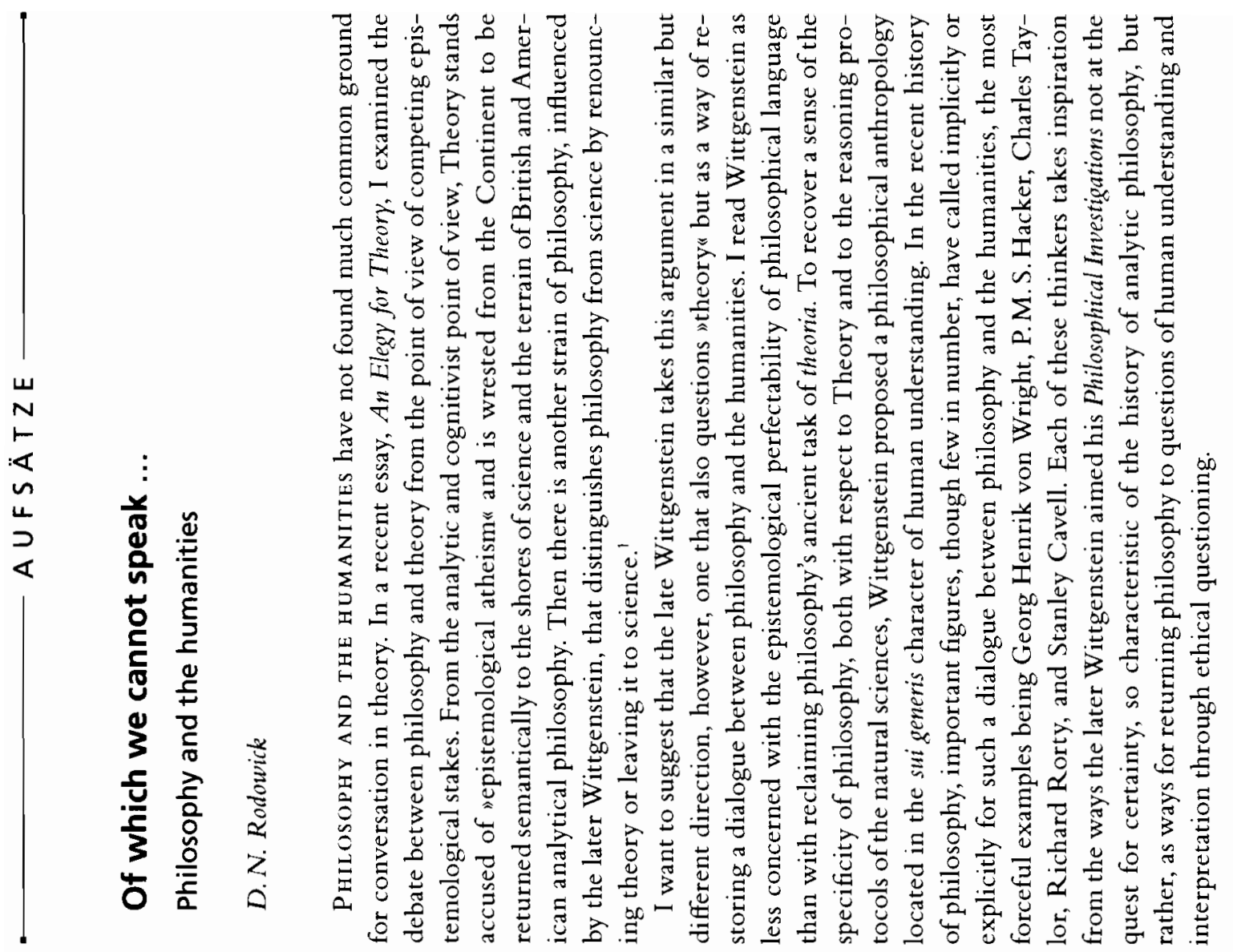

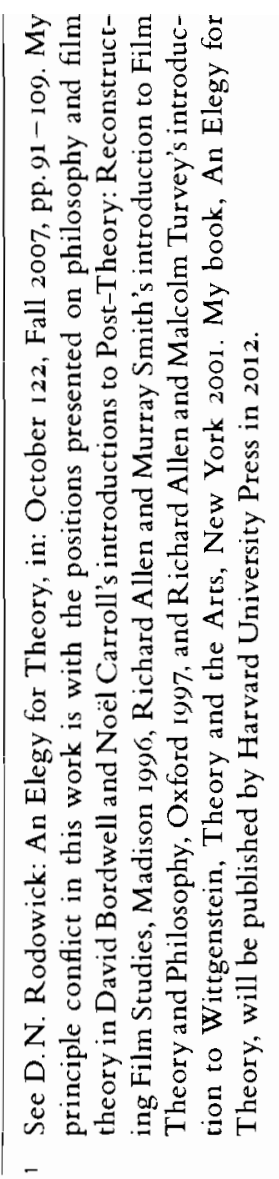




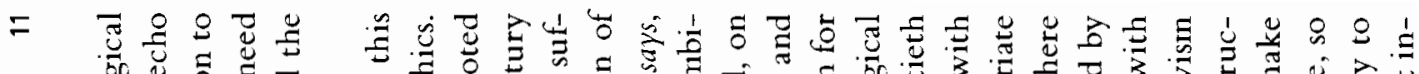

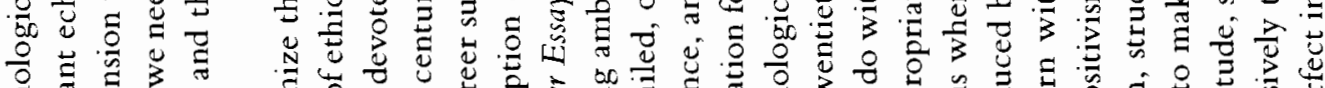

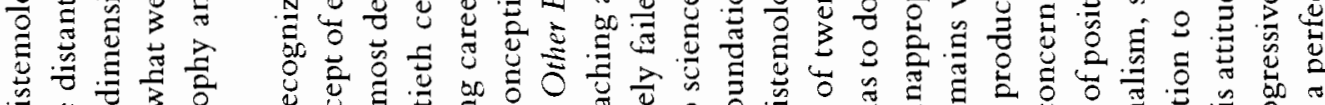

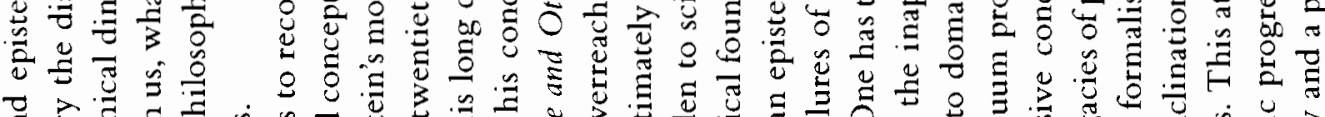

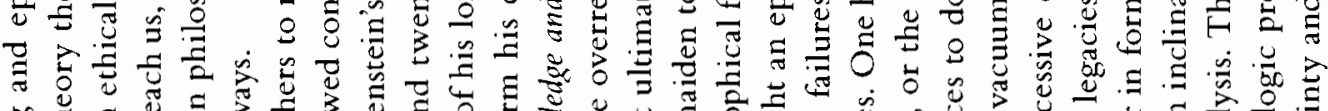
a

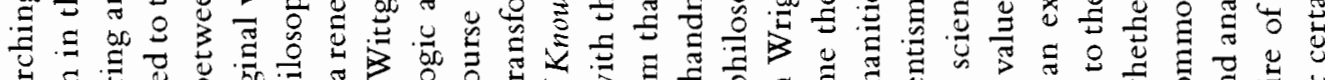

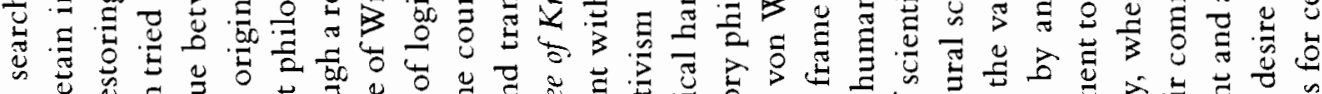

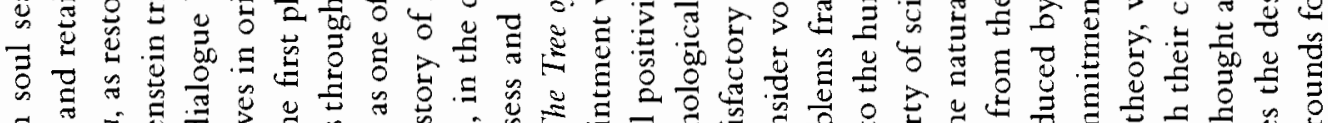

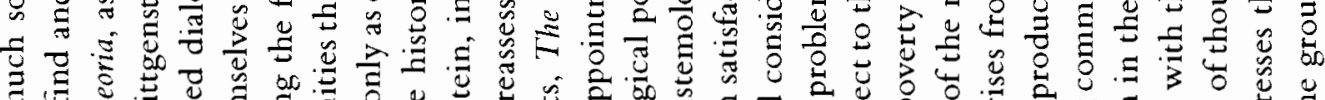

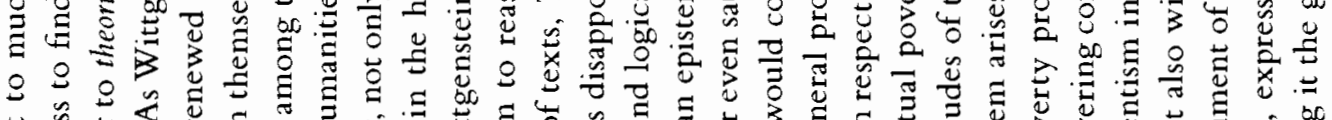

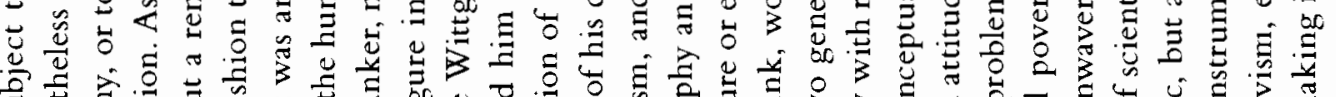

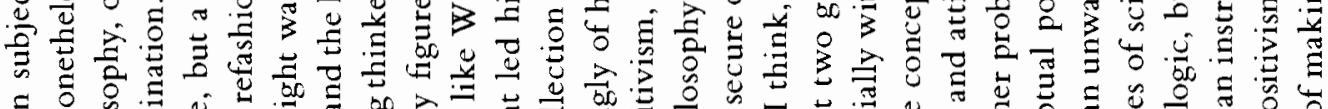

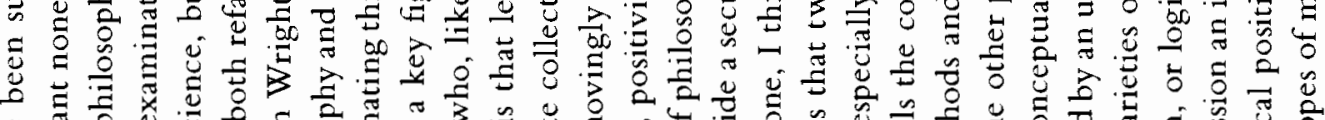

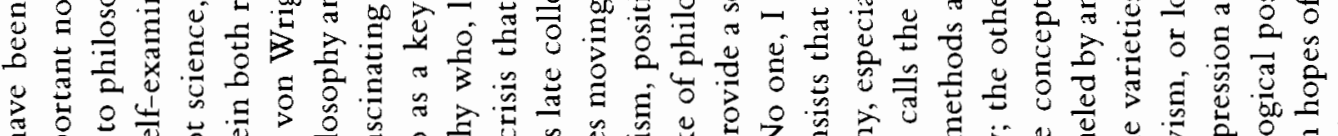

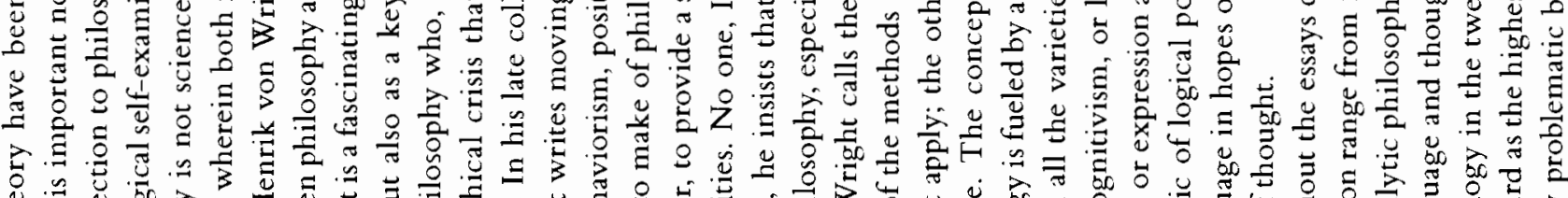

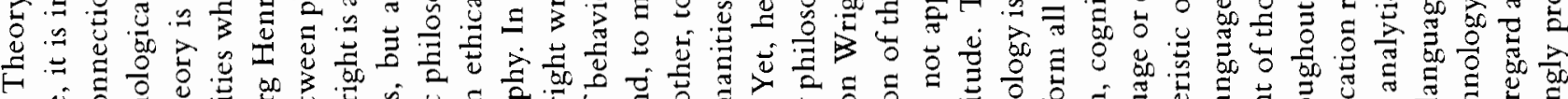

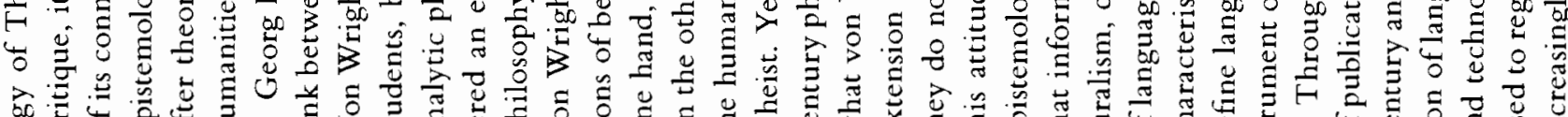

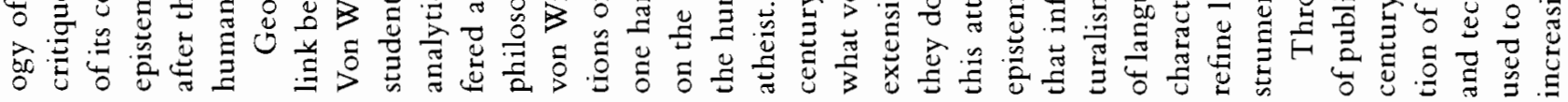

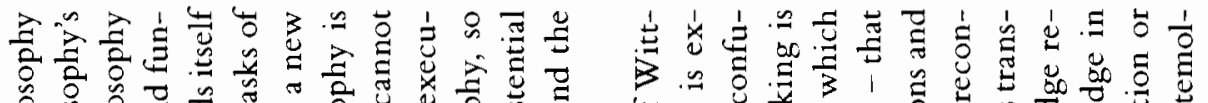

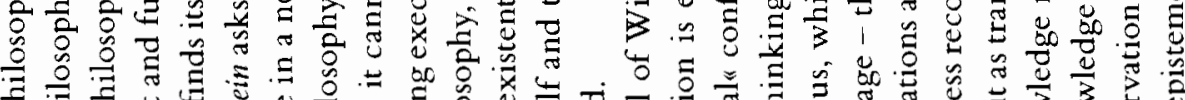

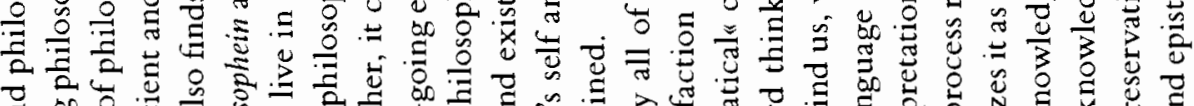

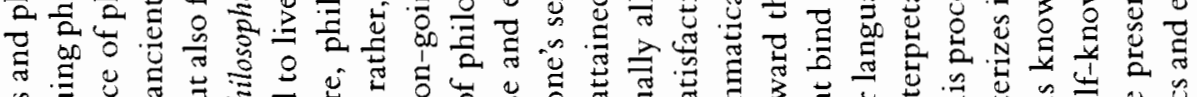

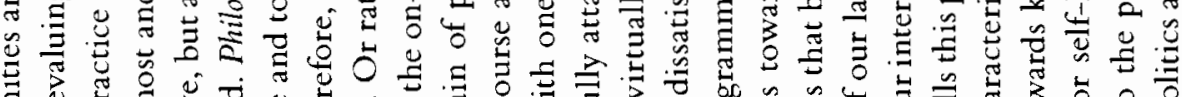

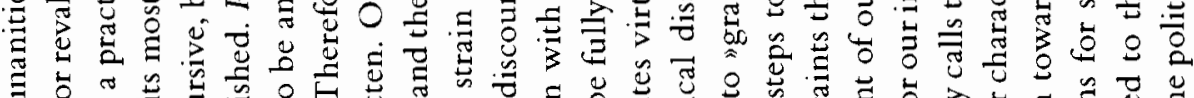

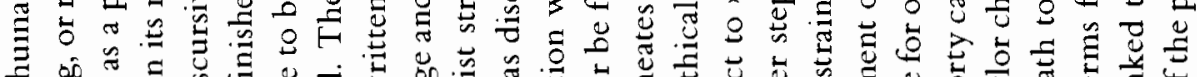

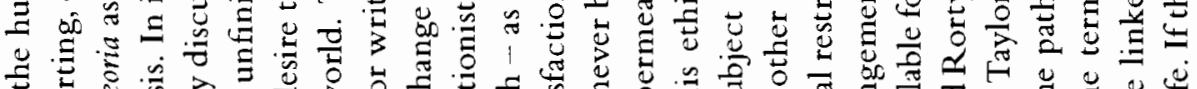

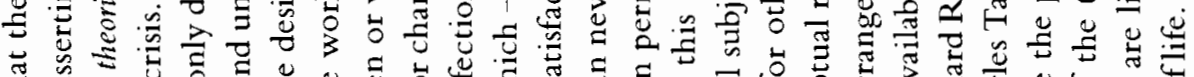

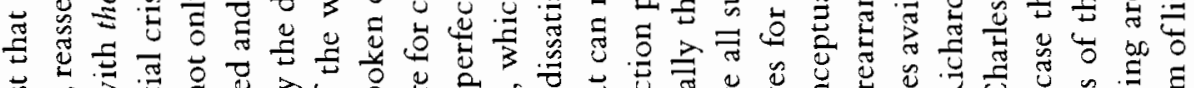

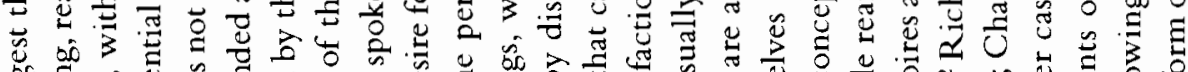

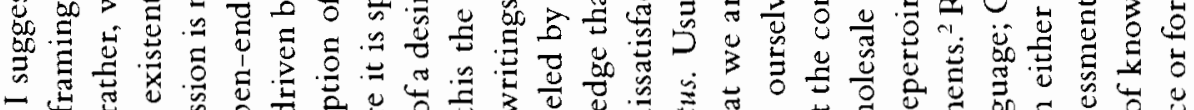

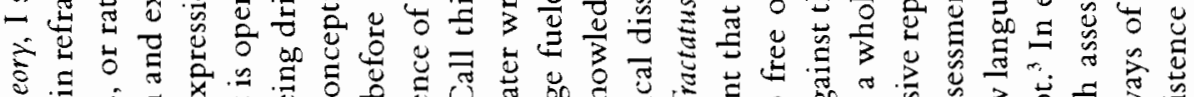

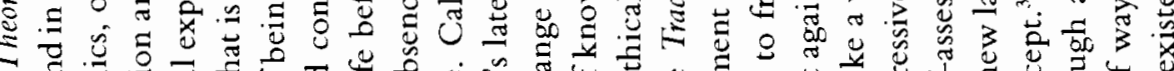

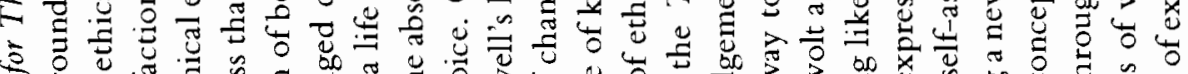

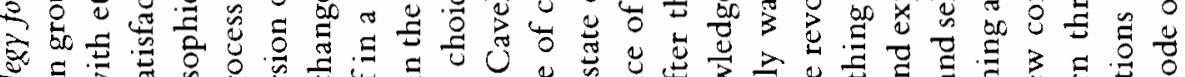

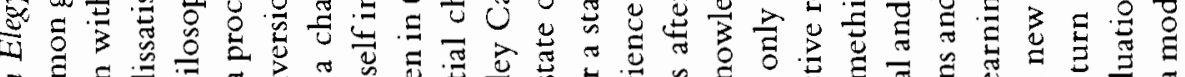

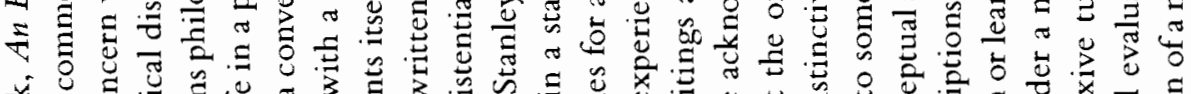

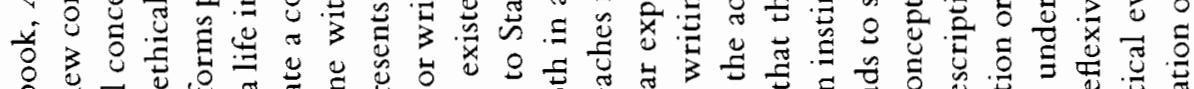

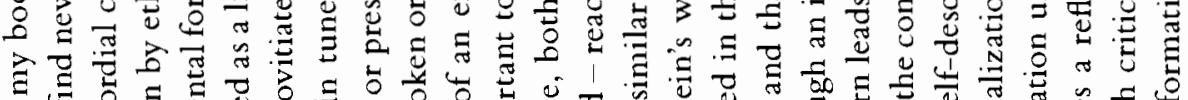

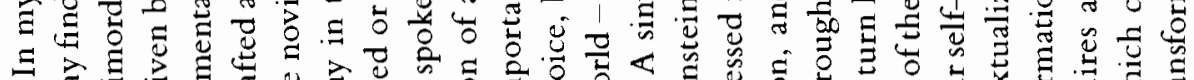

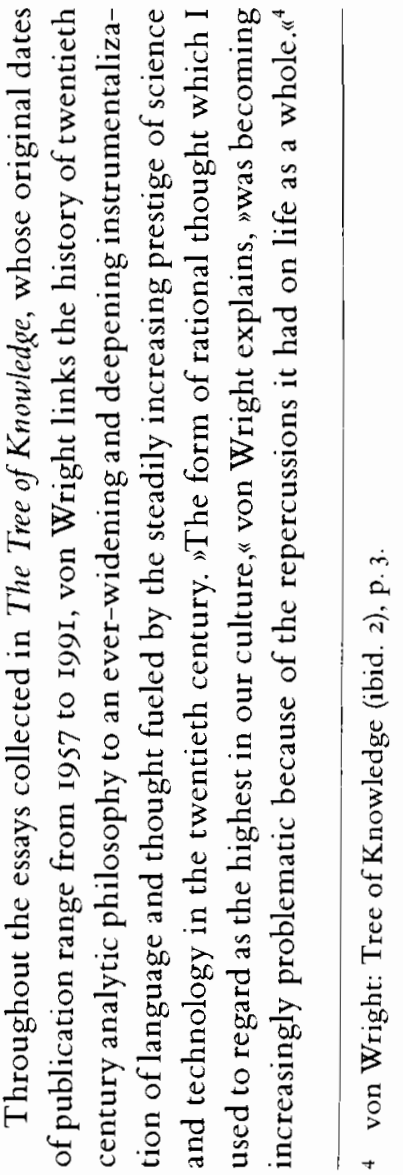

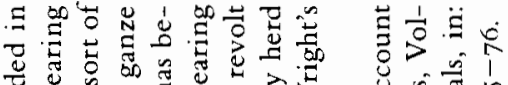

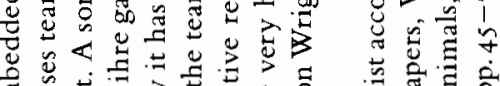

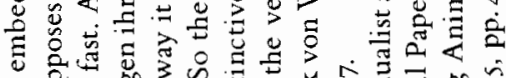

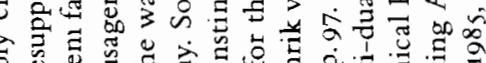

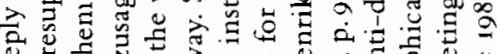

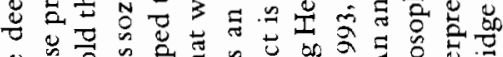
U.

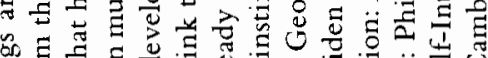

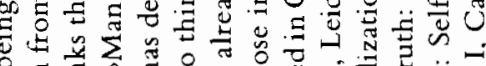

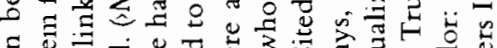

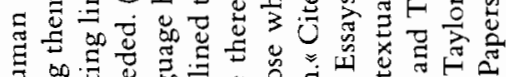

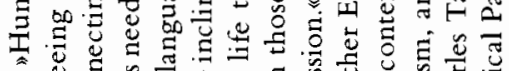
is

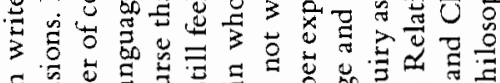

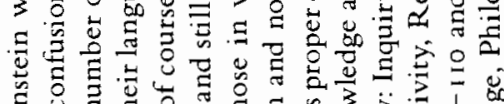

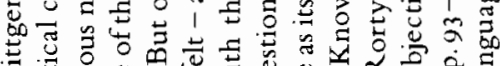

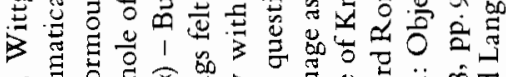

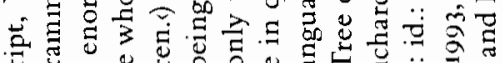

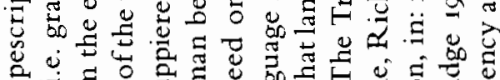

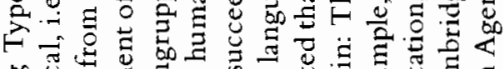
की

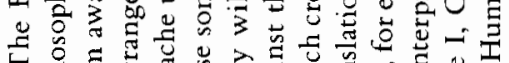

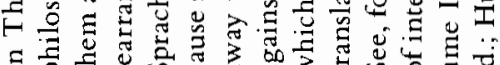




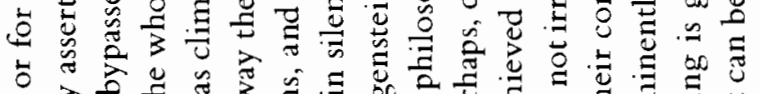
पे

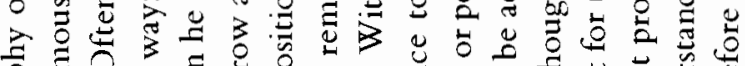

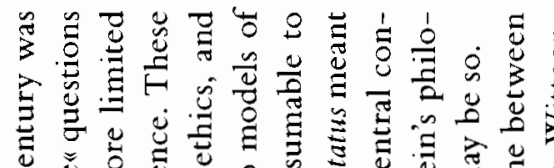

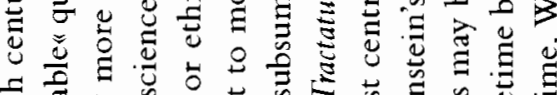

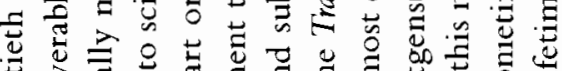
○े

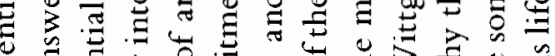

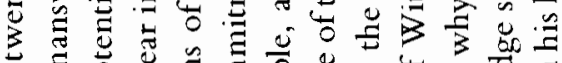

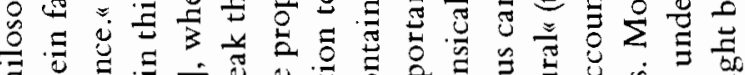

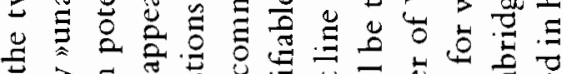

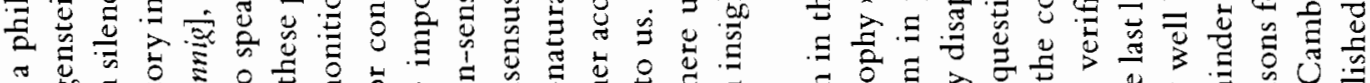

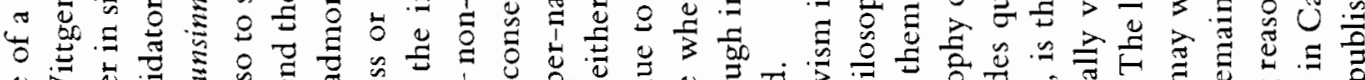

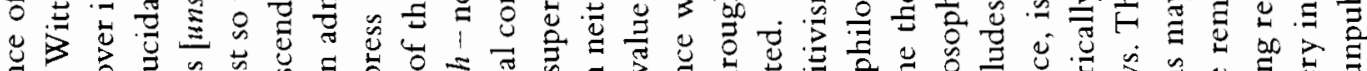

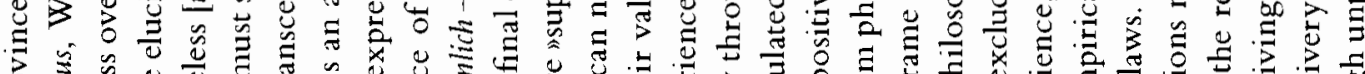

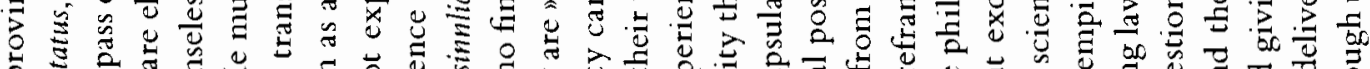

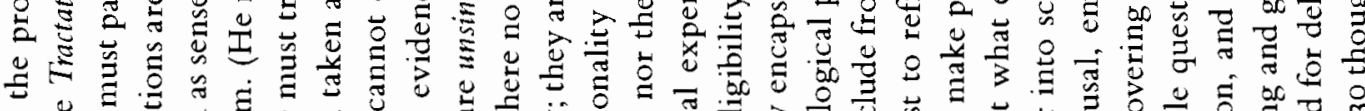

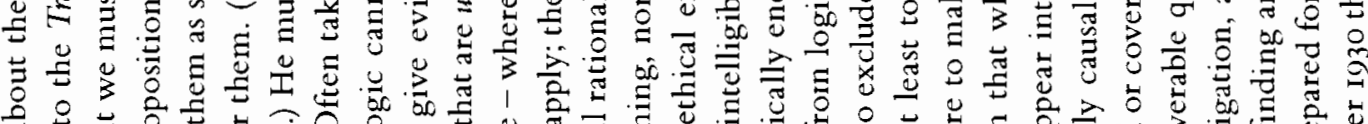

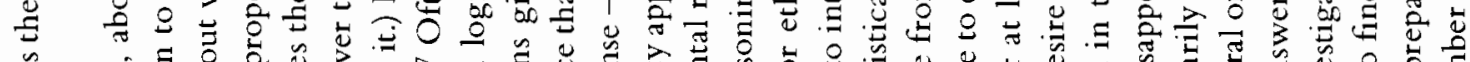

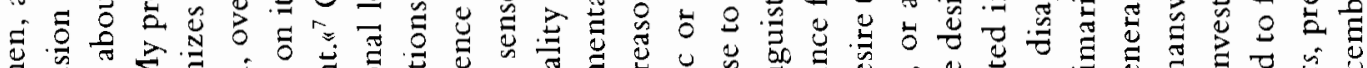

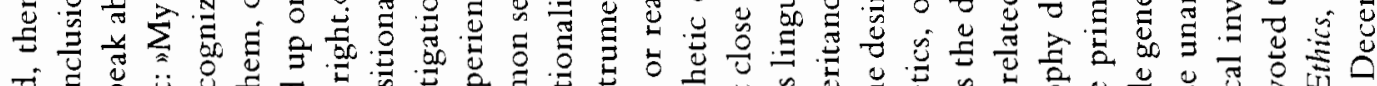

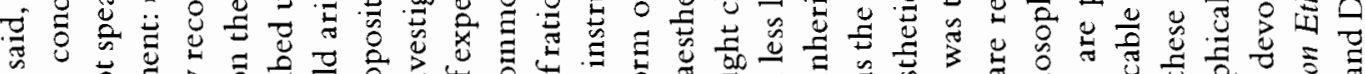

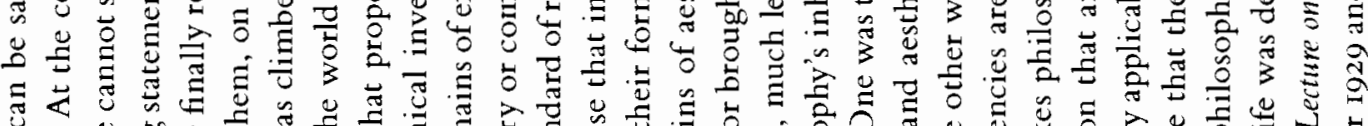

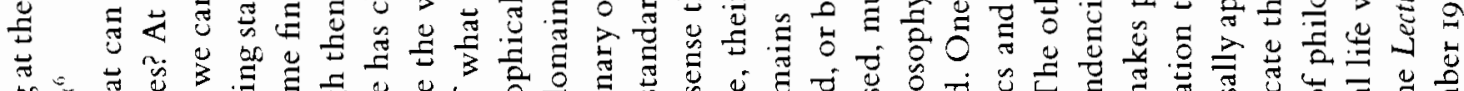

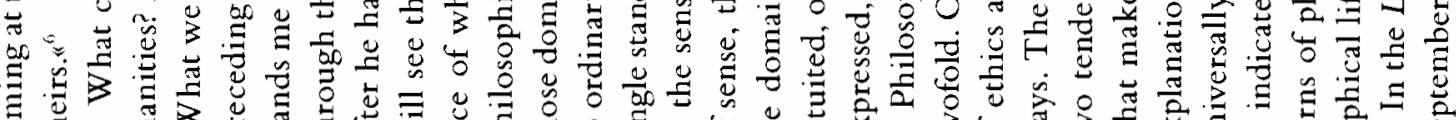

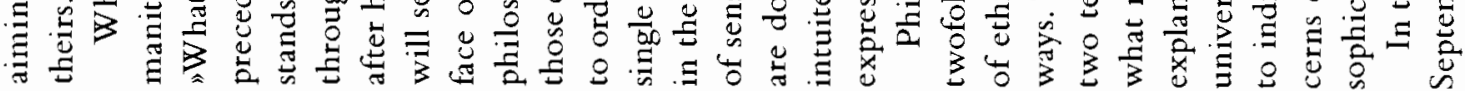

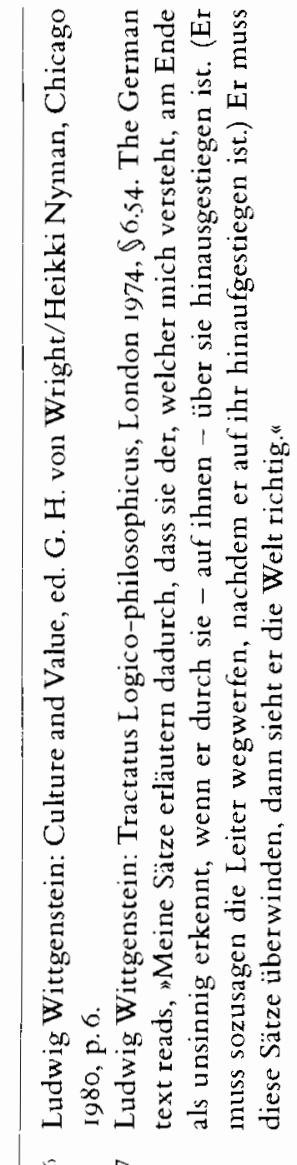

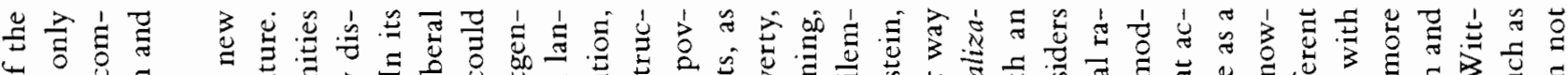

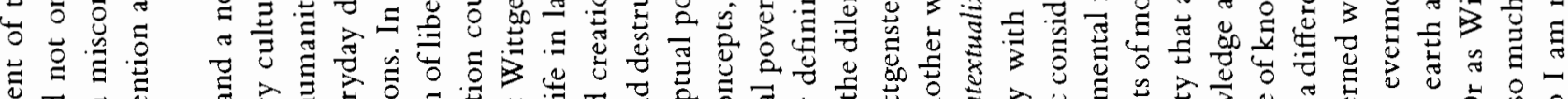

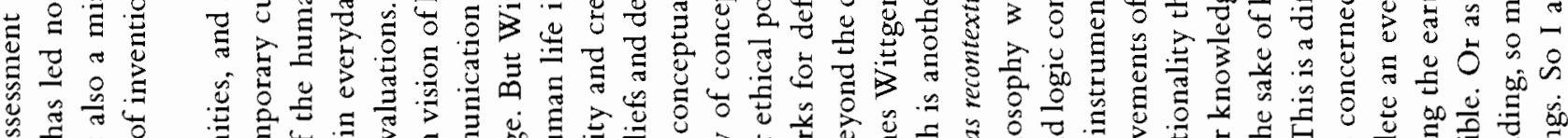
可 气

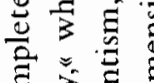
$\hat{=}$ $\rightarrow$ 范

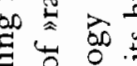
苟

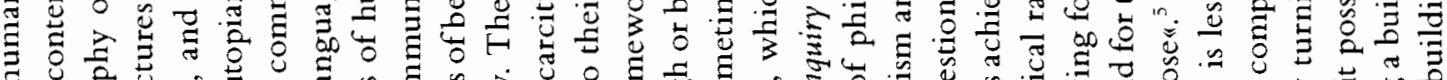

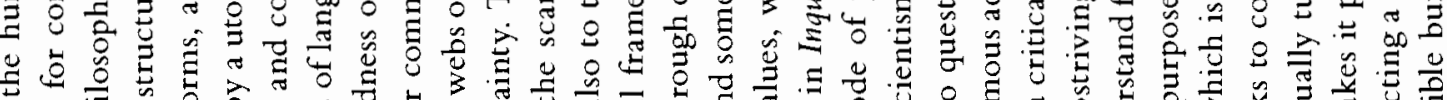

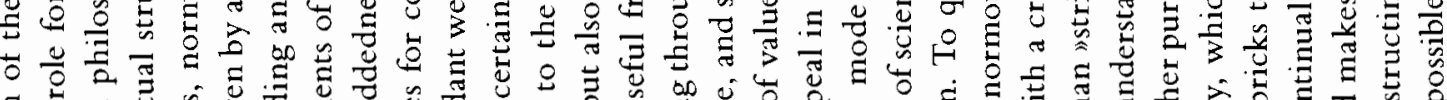

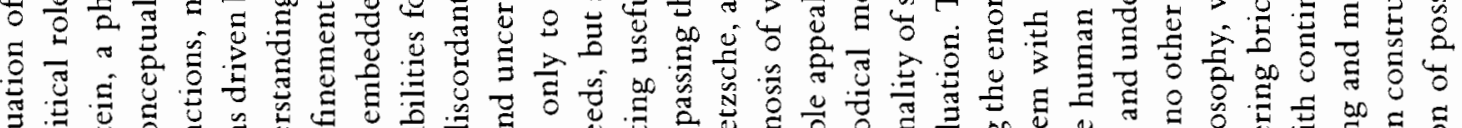

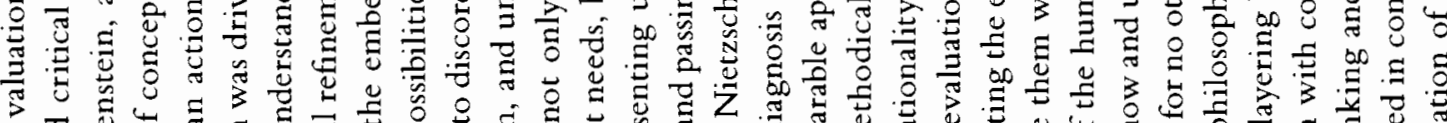
उ

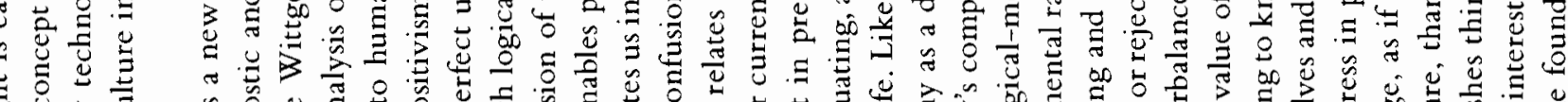

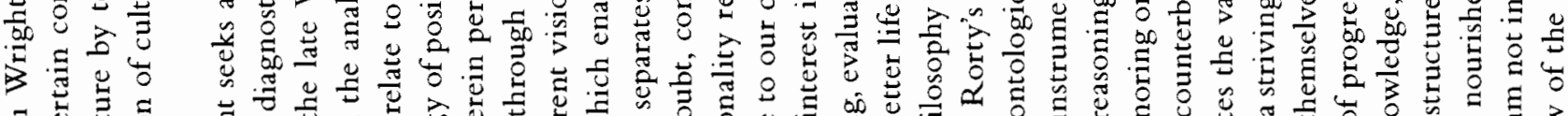

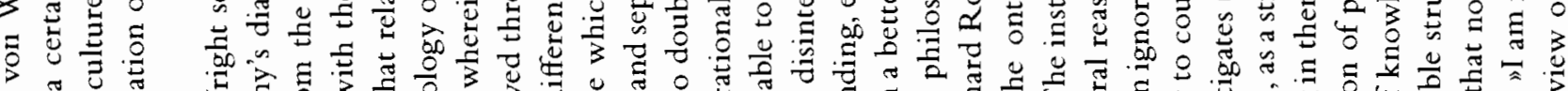

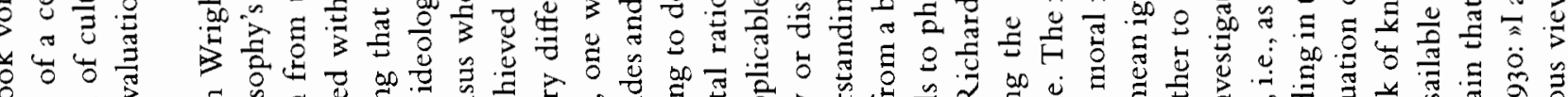

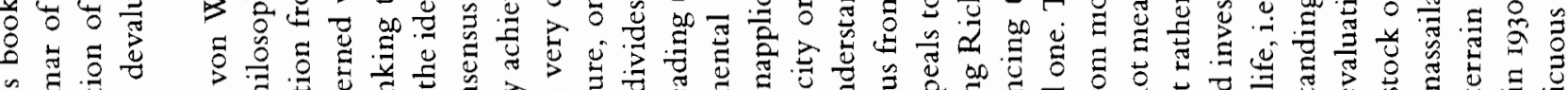

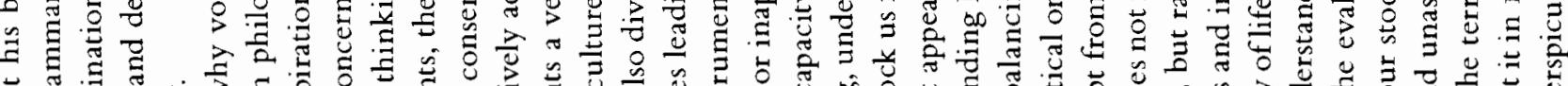

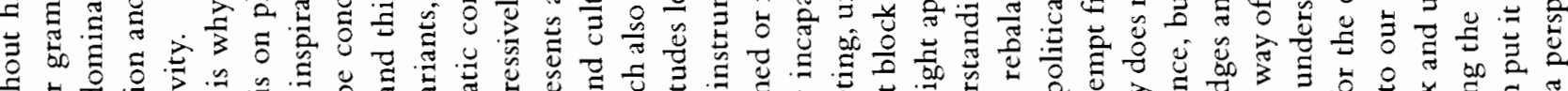

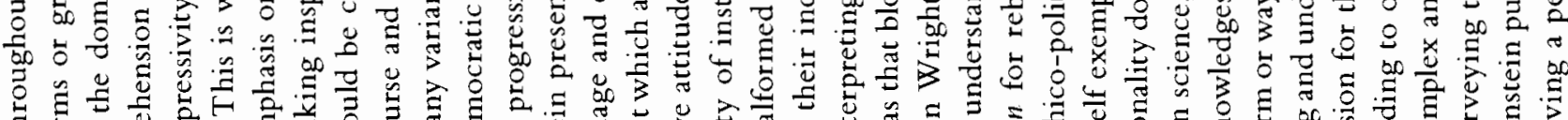

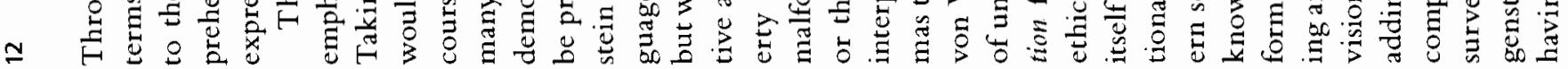




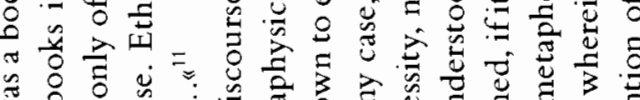

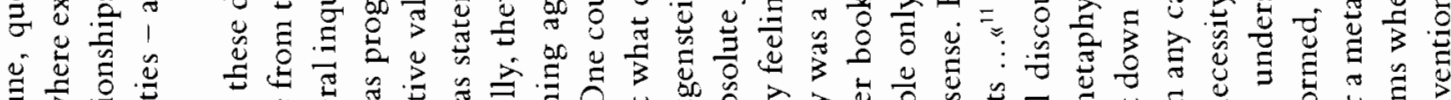

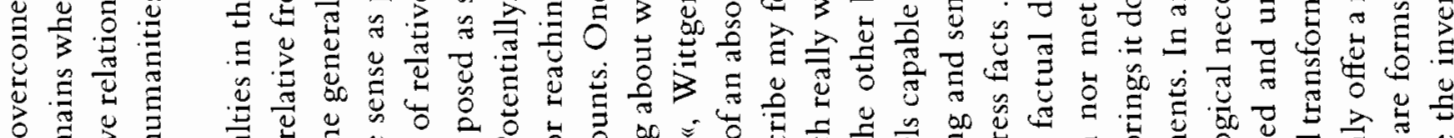

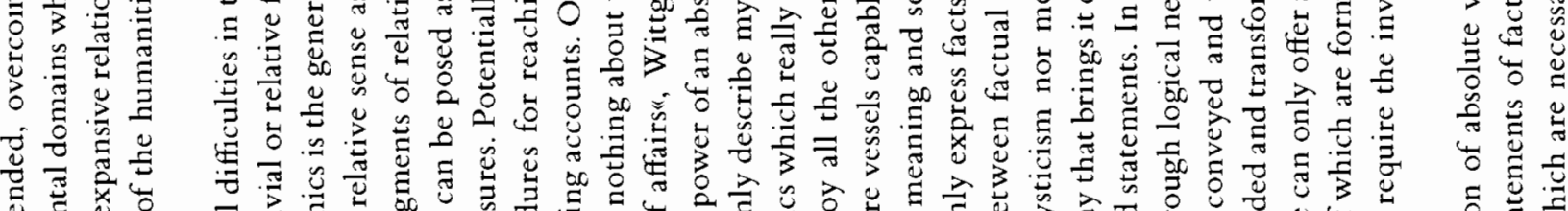

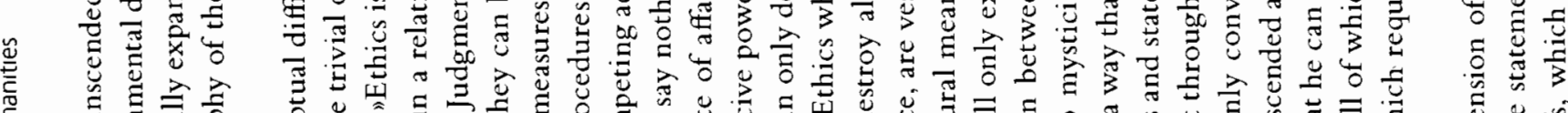

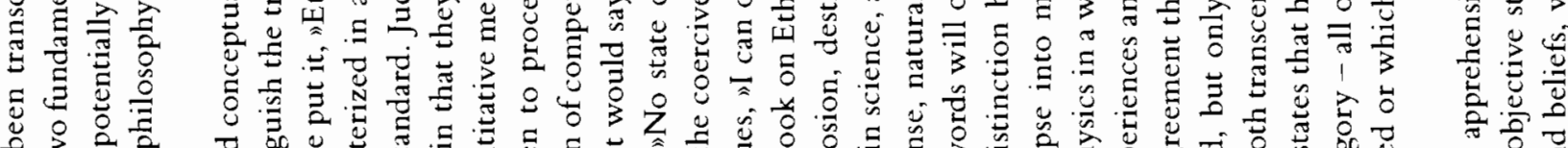

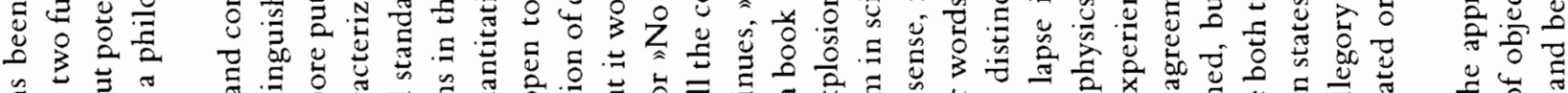

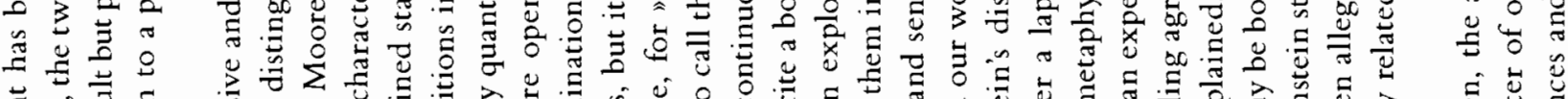

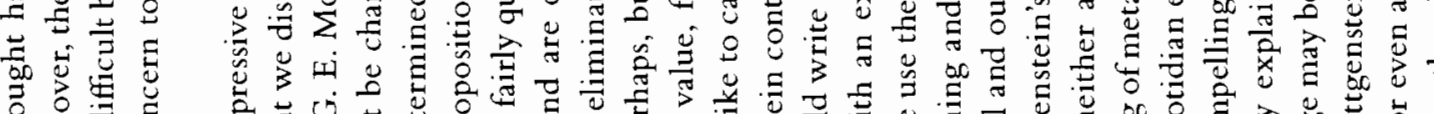

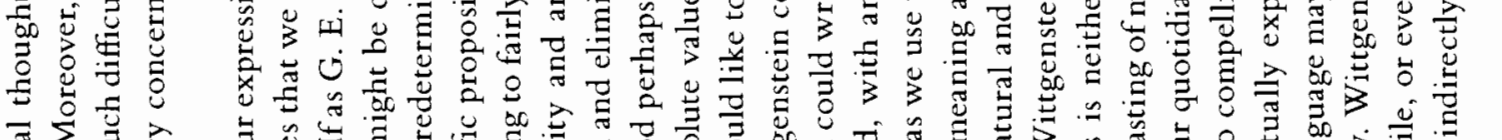

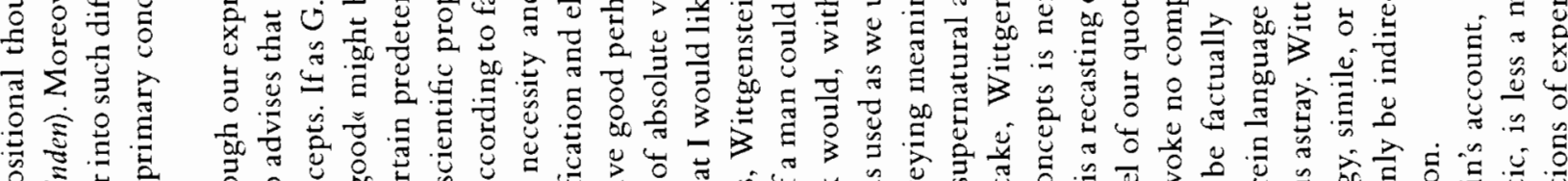

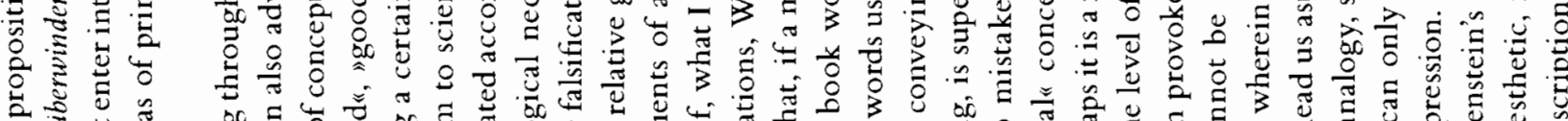

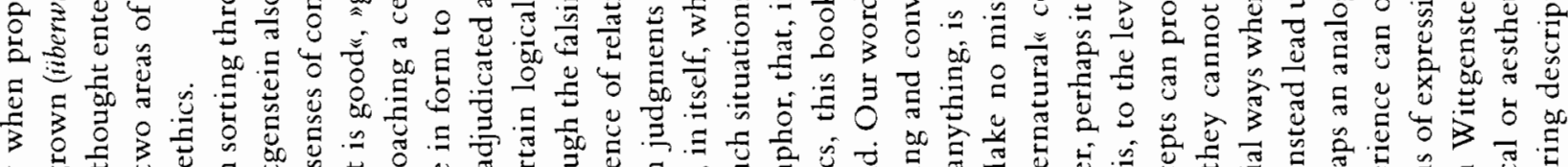

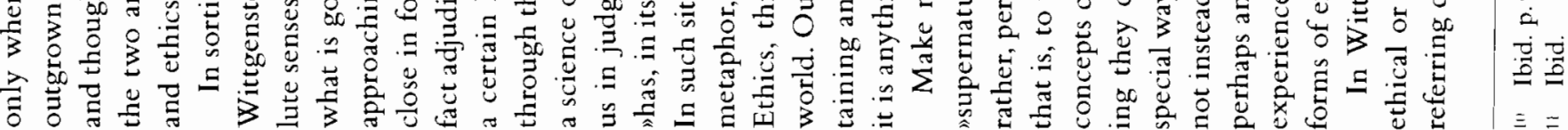

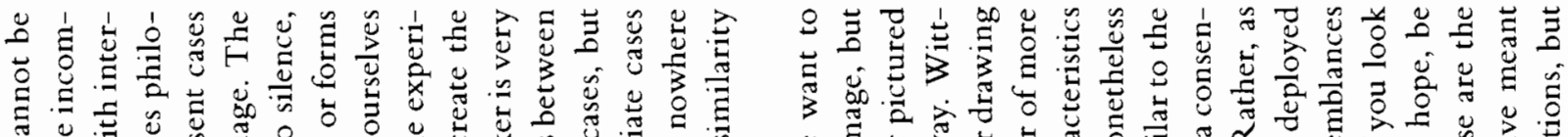

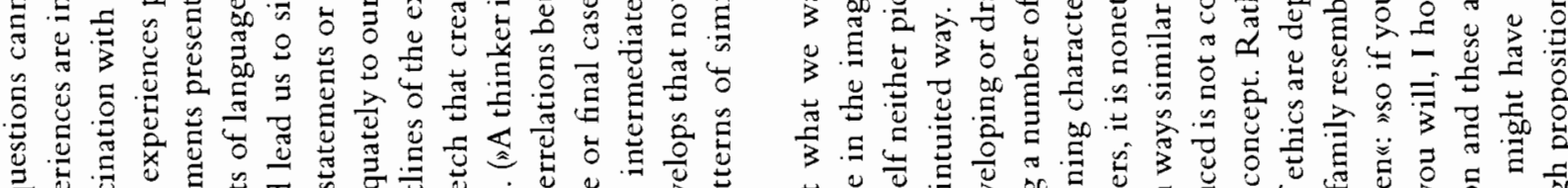

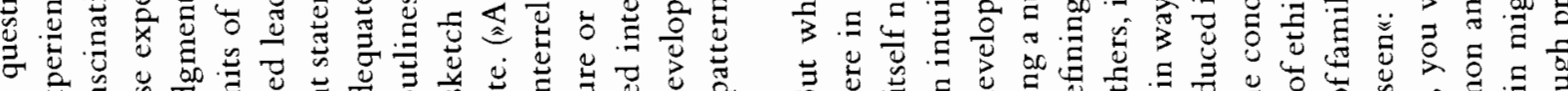

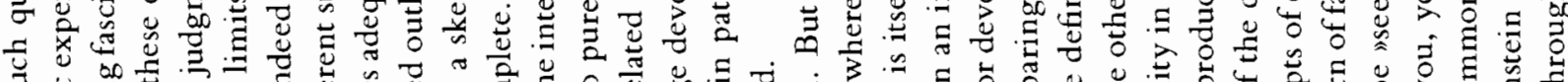
$\breve{g}$ б

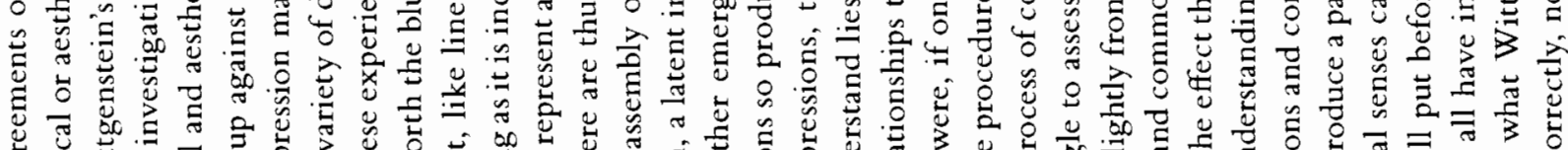

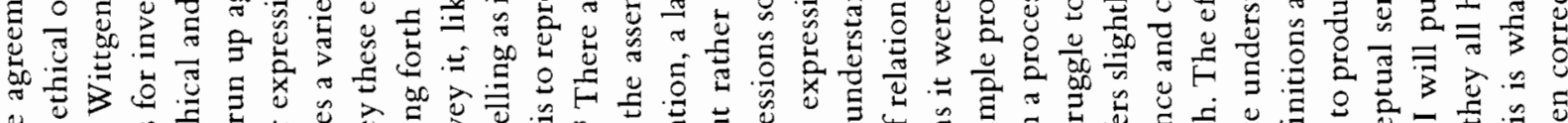

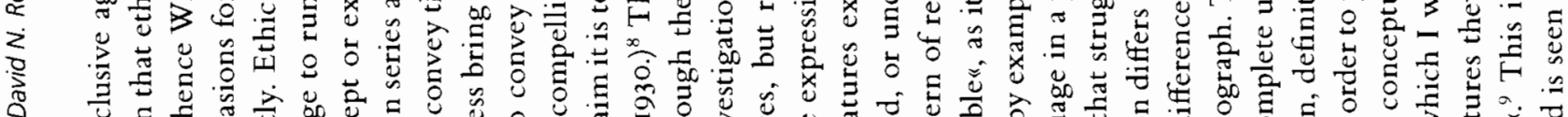

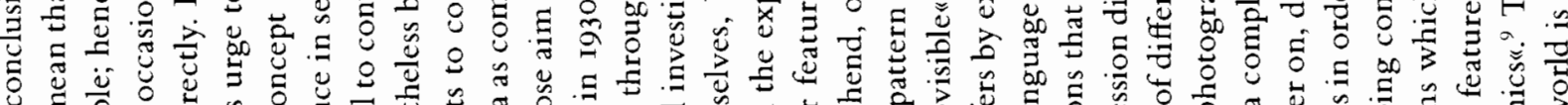

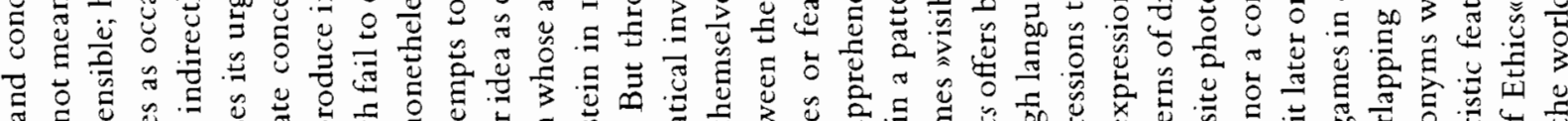

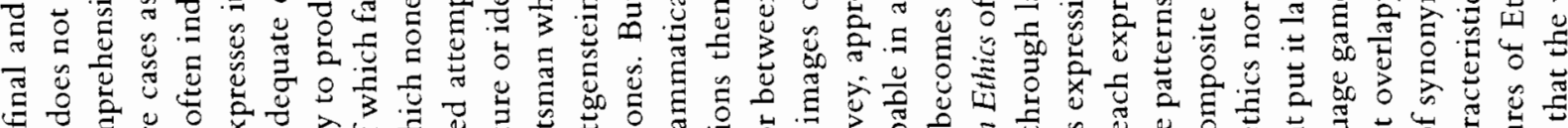

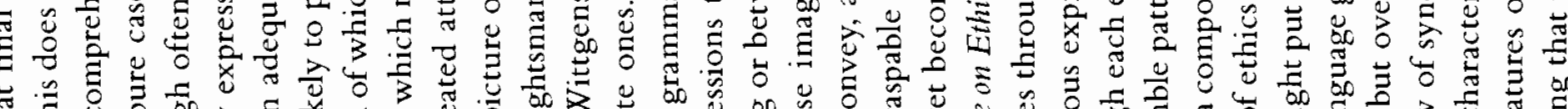

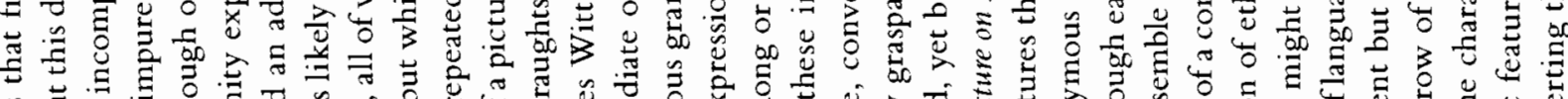

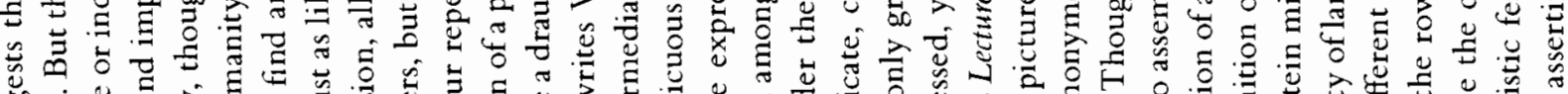

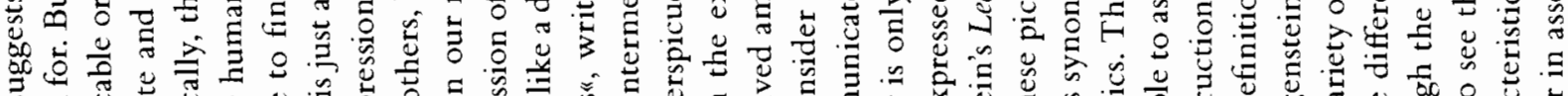

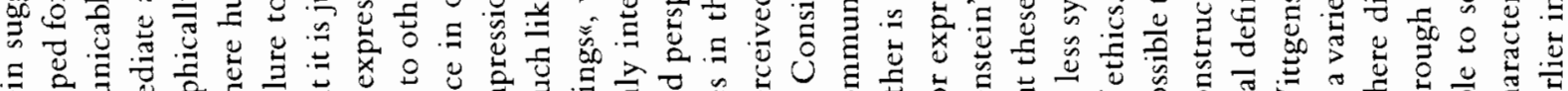

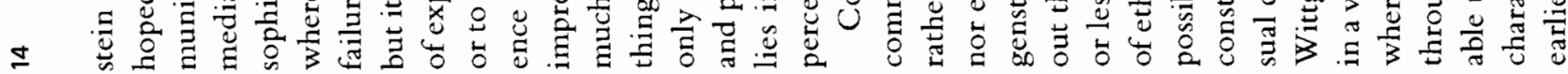


$=$

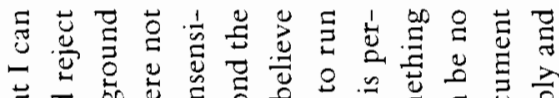

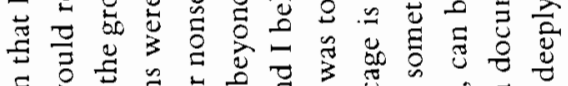

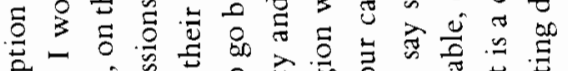

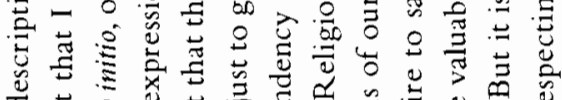

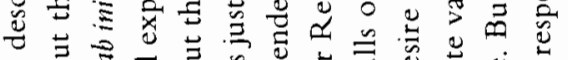

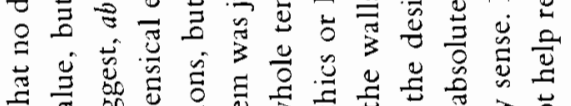

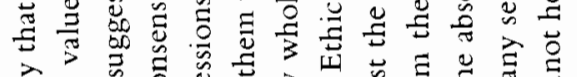

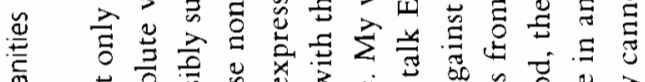

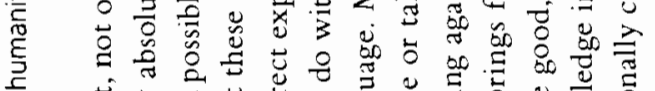

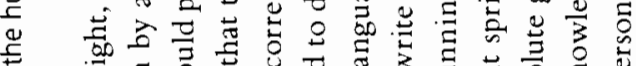
늘

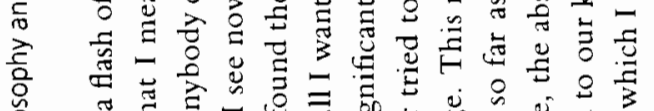

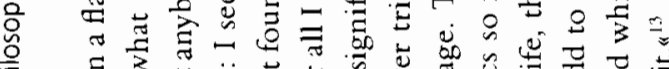

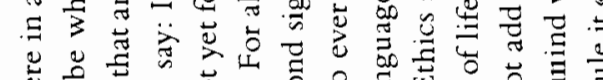
苟苛志

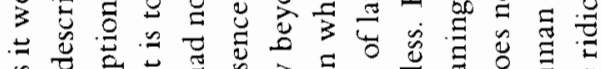

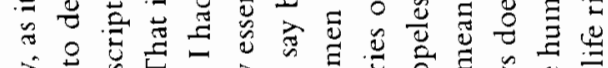

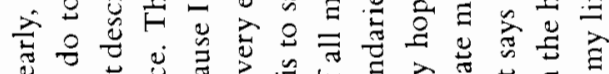

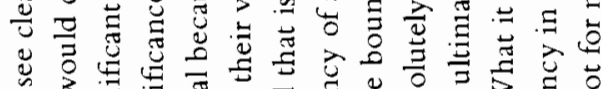

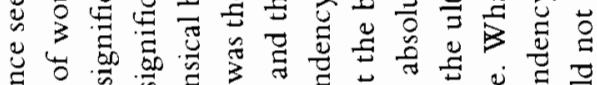

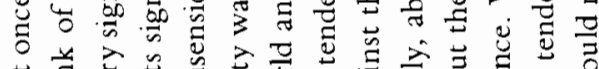

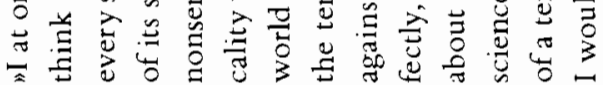

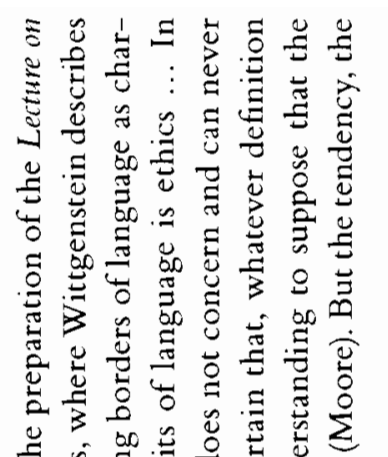

壳

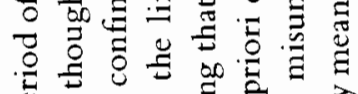

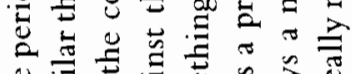

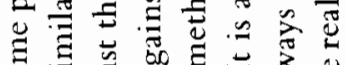

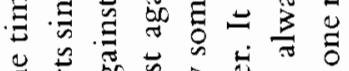

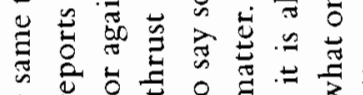

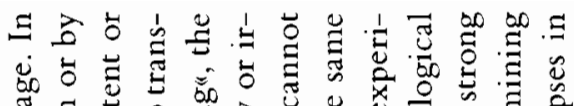

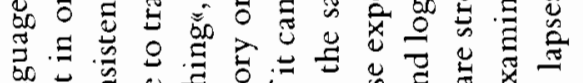

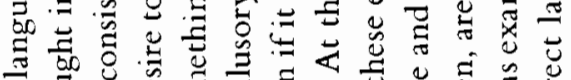

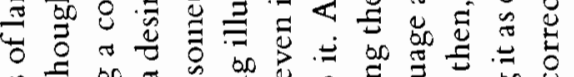

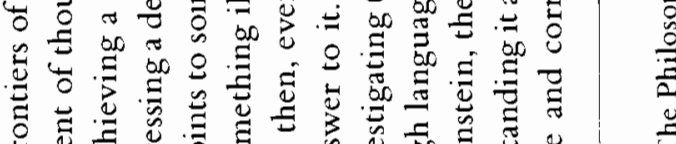

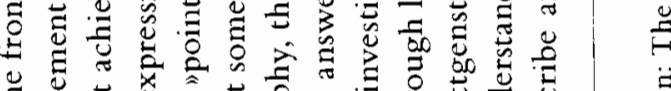

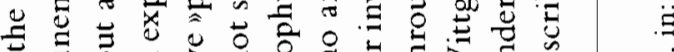

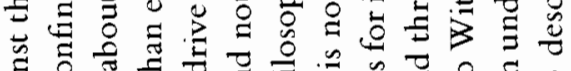

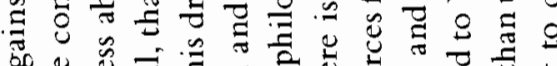

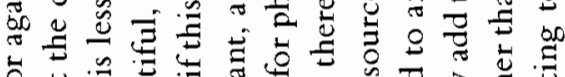

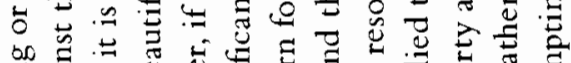

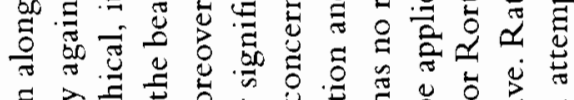

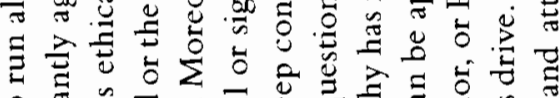
I

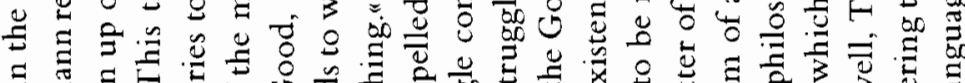

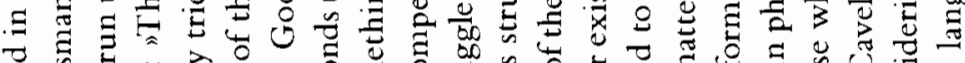

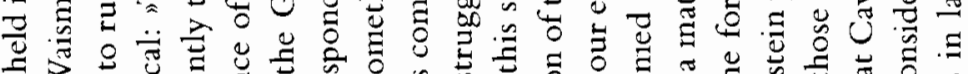

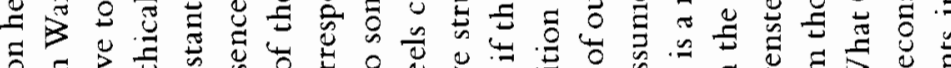

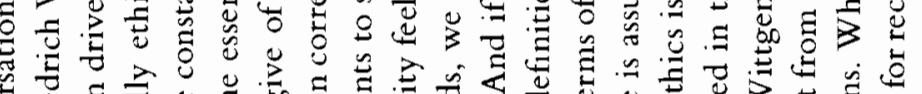

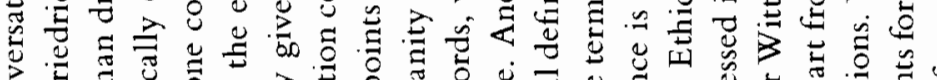

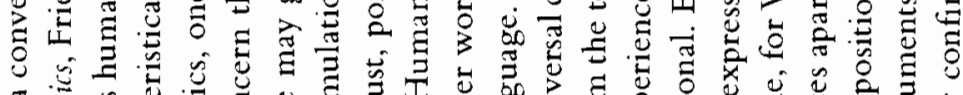

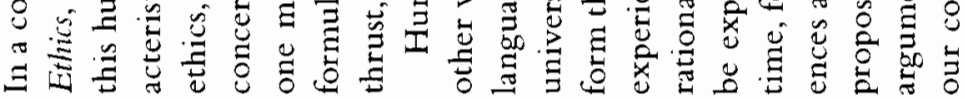

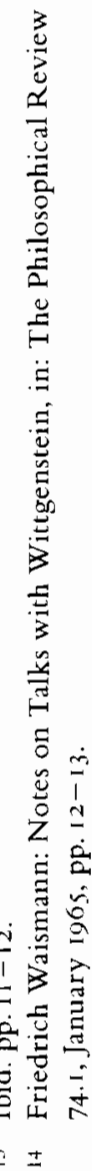

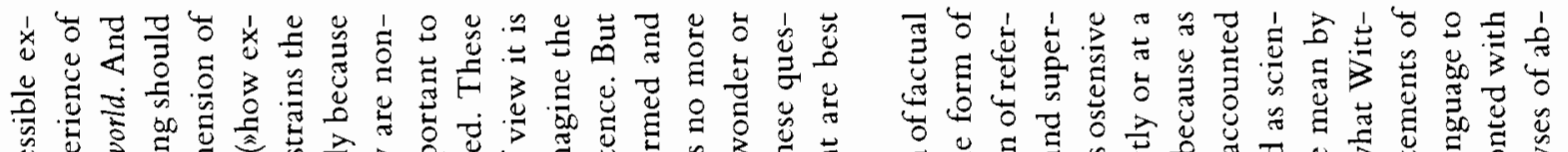

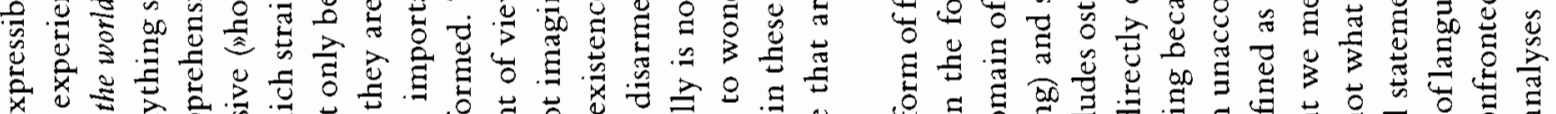

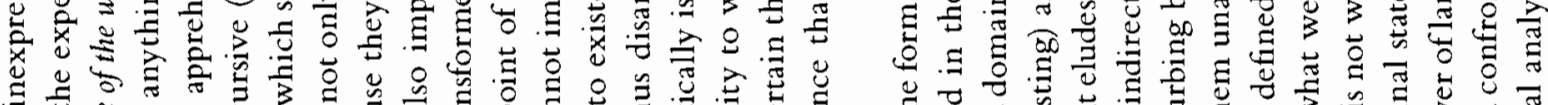

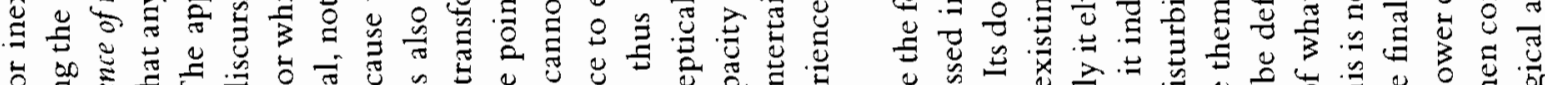

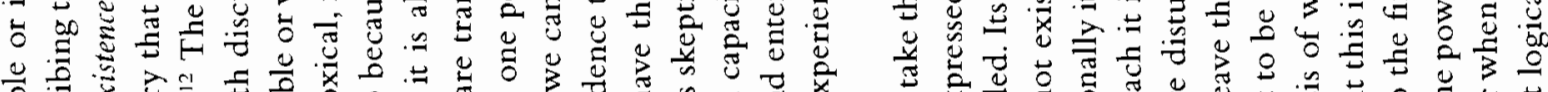

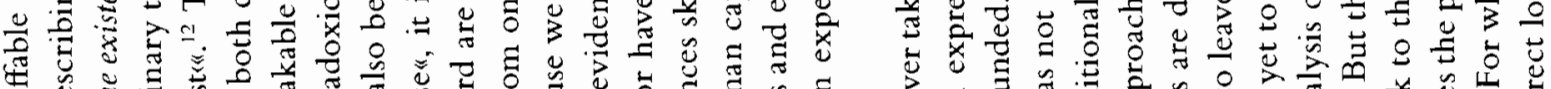

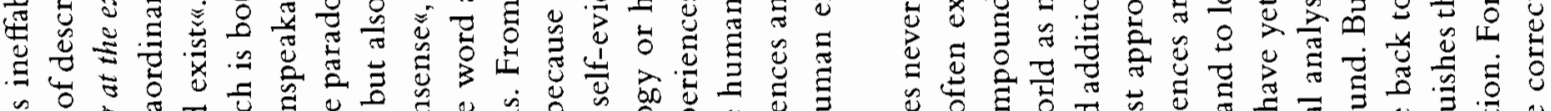

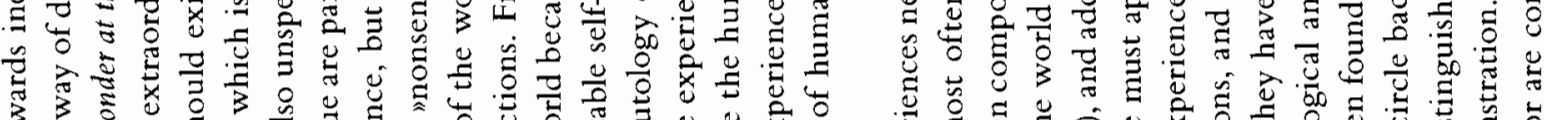

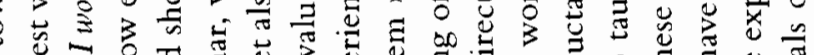

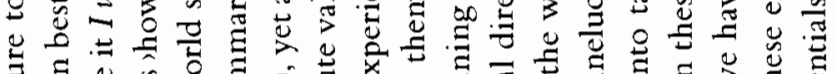

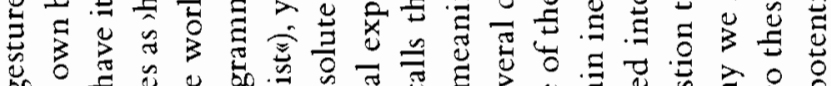

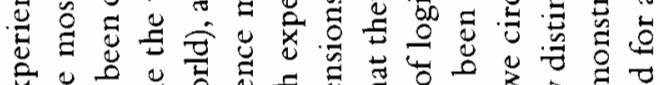

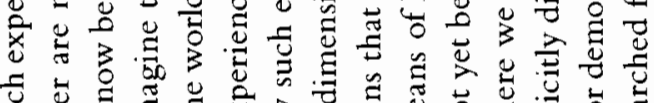

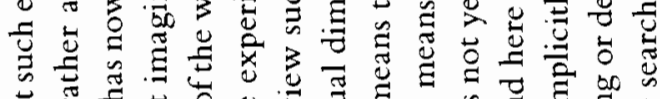

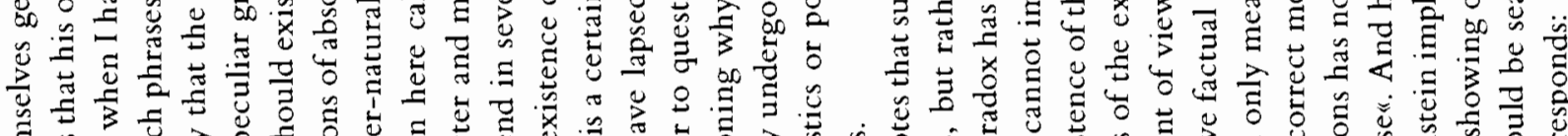

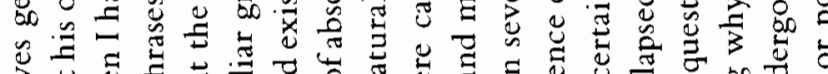

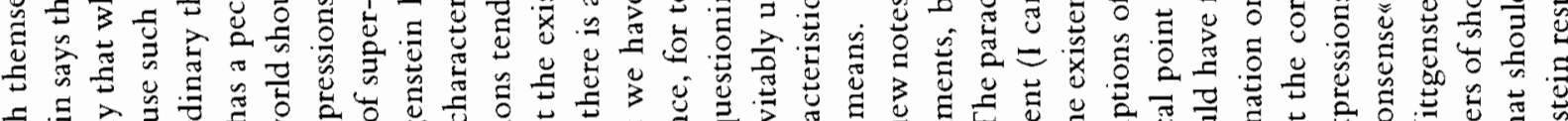

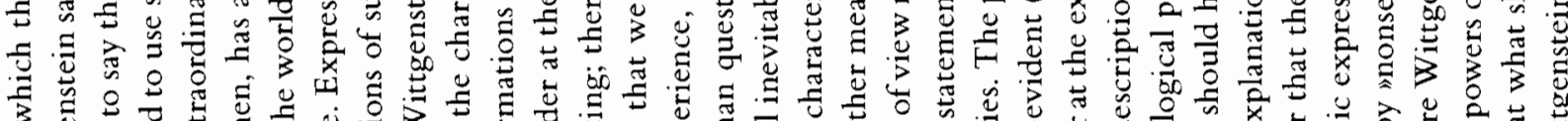

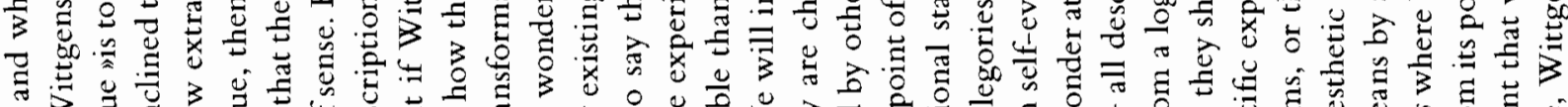

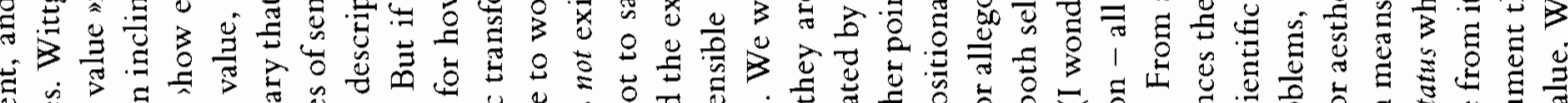

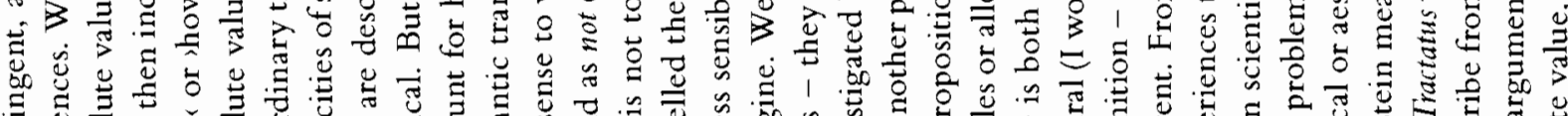

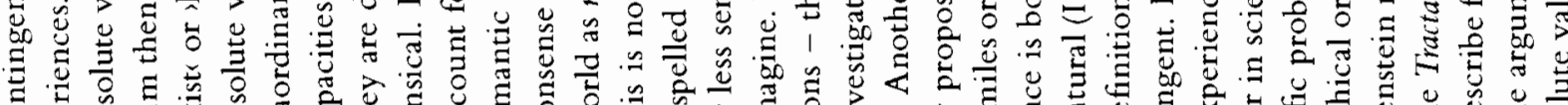

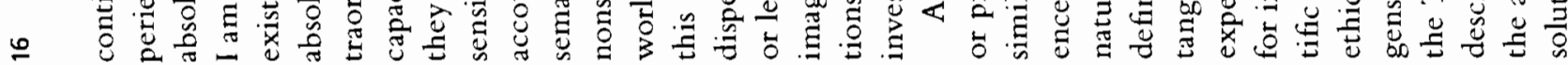




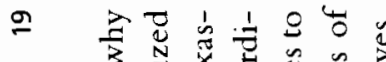

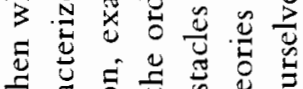
至过 î

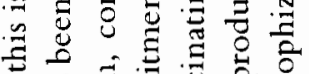

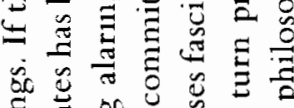
凹 ป

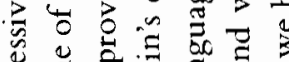

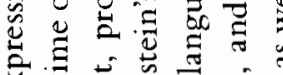

侪

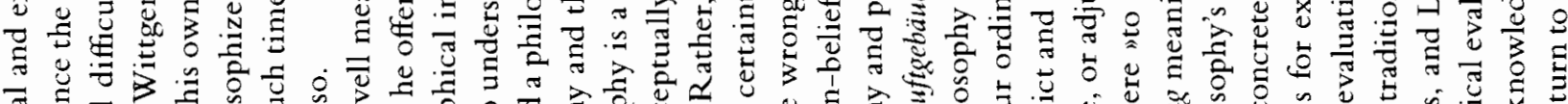

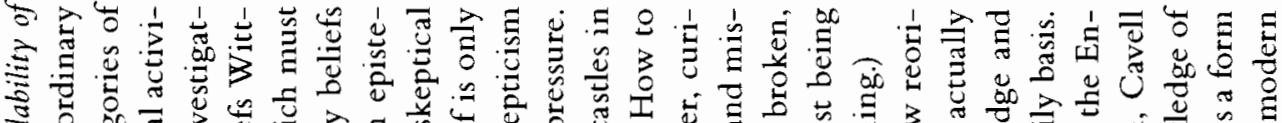

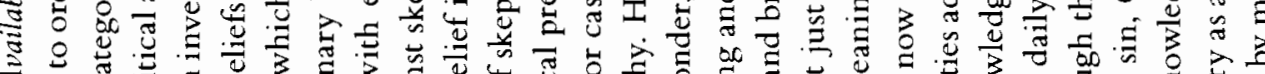

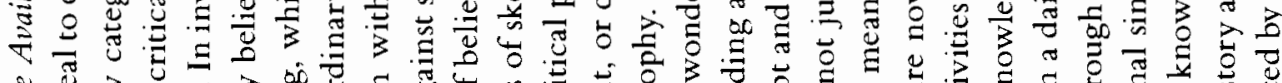

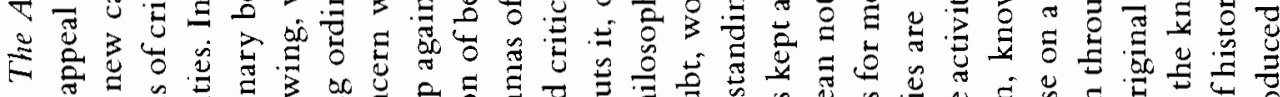

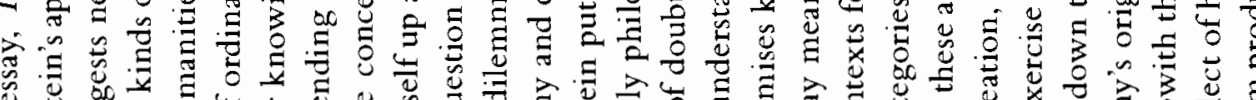

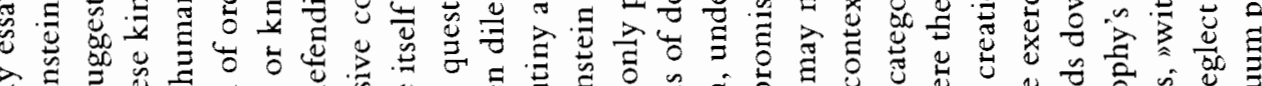

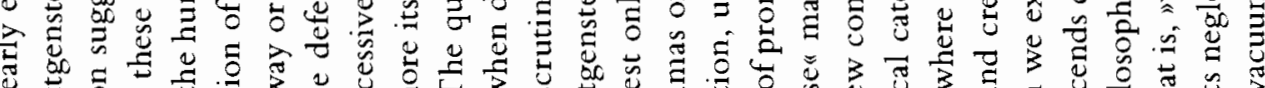

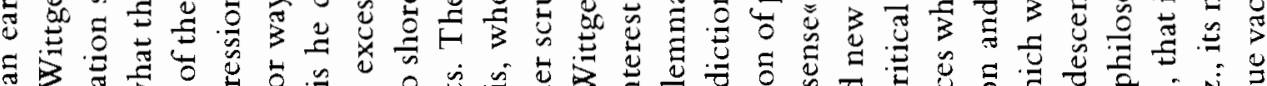

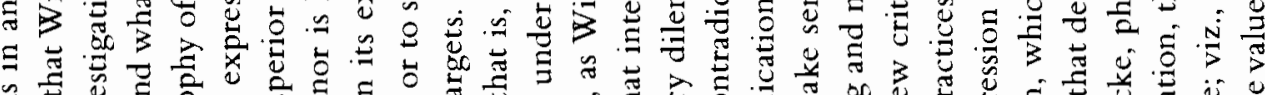

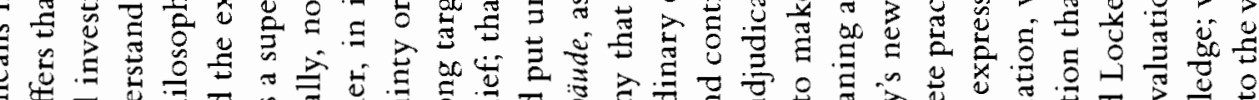

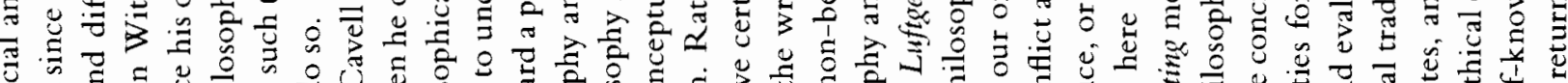

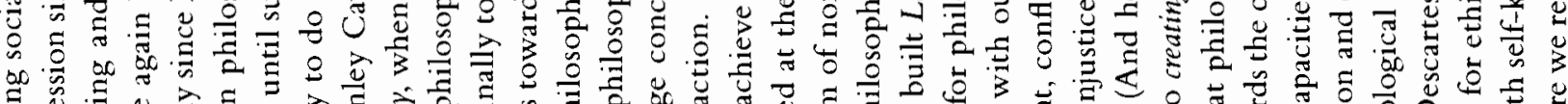

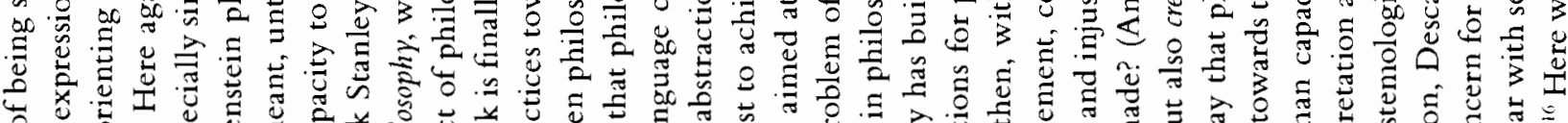

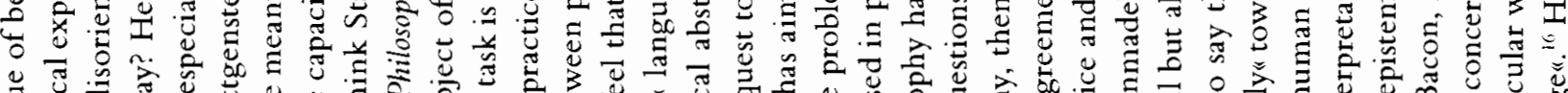

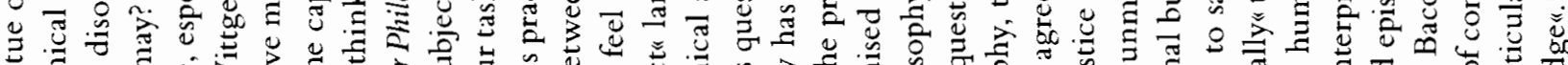

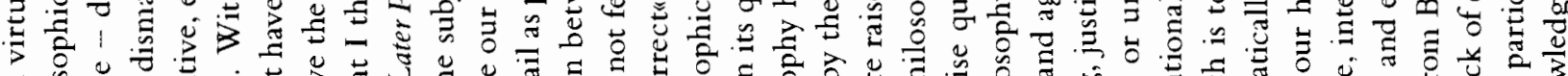

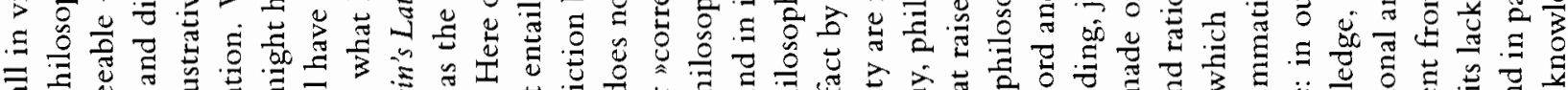

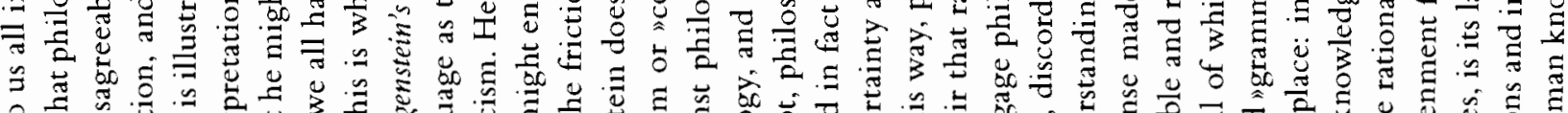

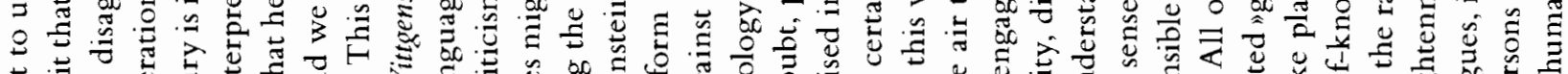

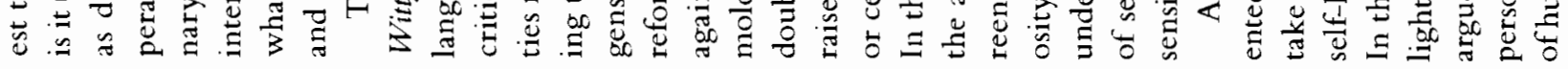

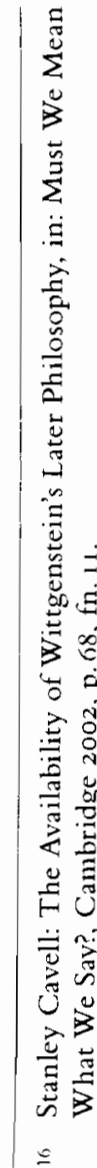

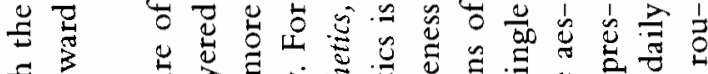

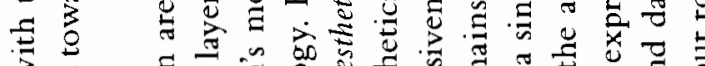

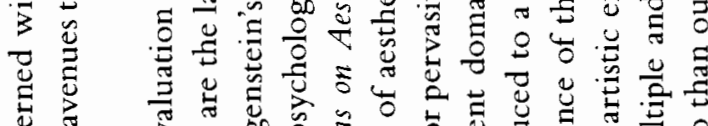

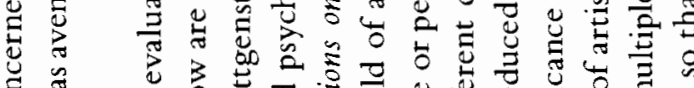

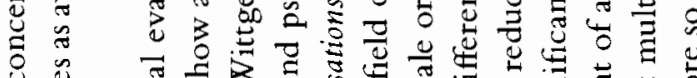

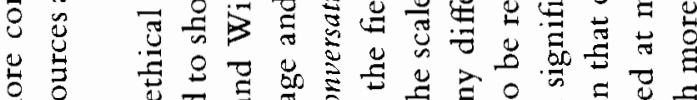

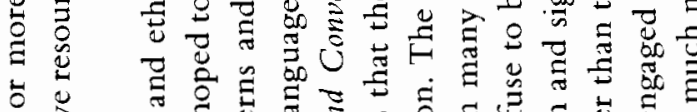

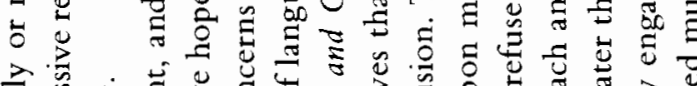

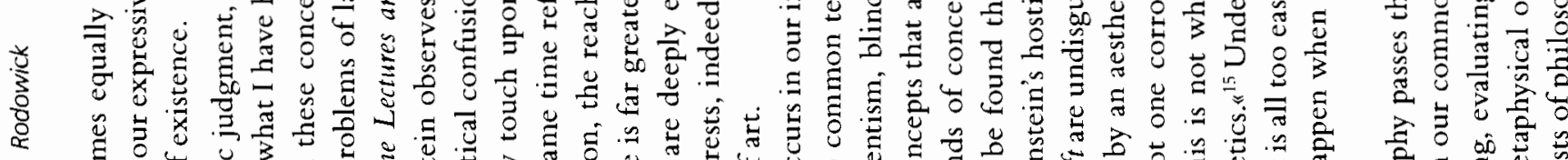

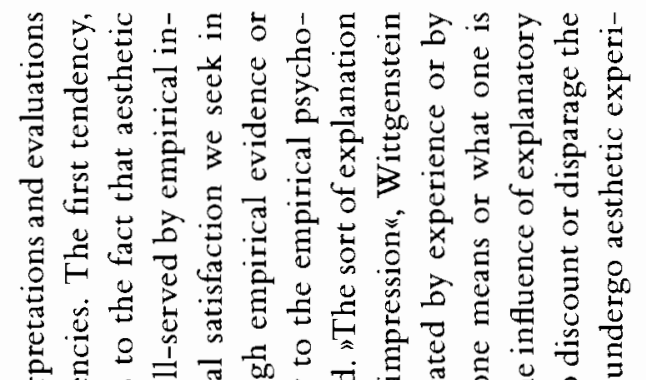

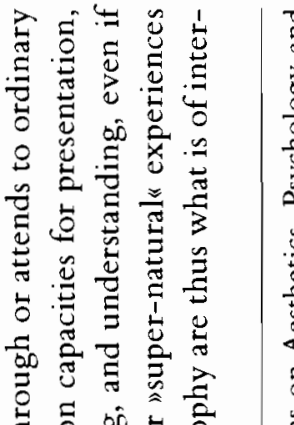

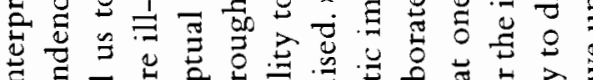

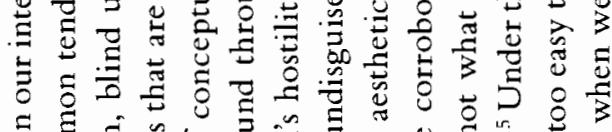

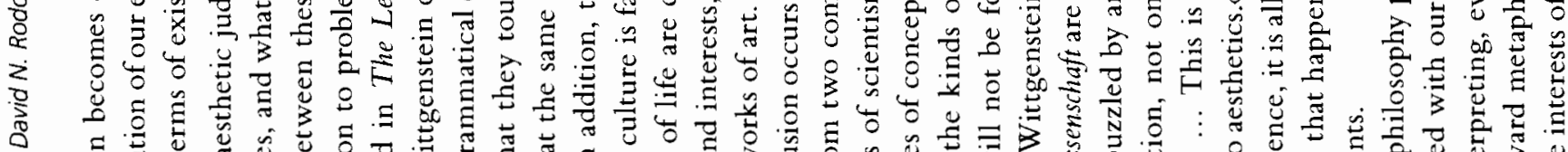

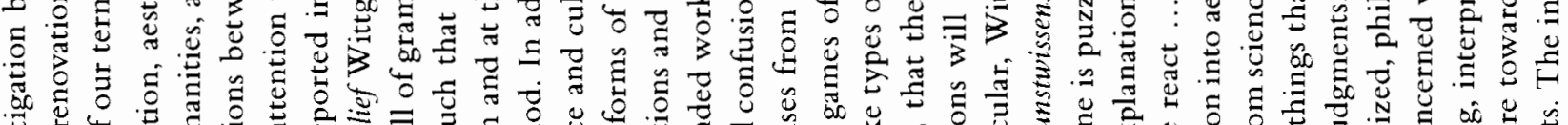

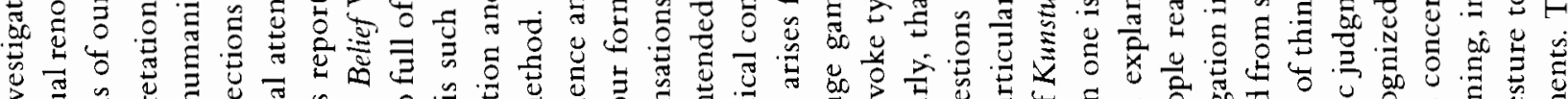

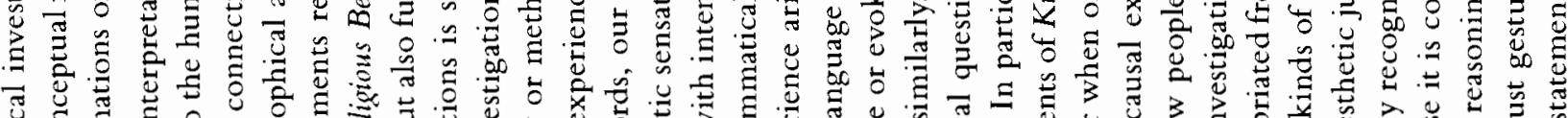

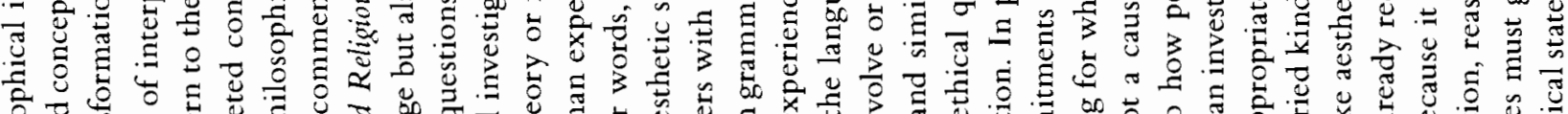

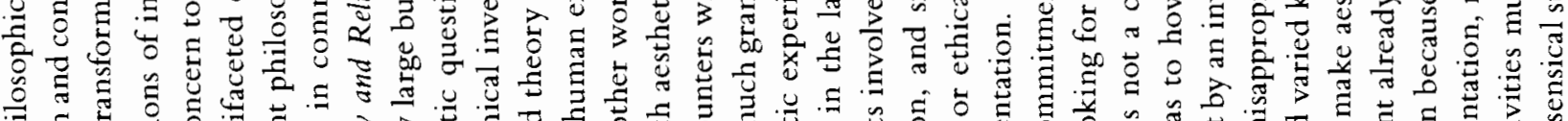

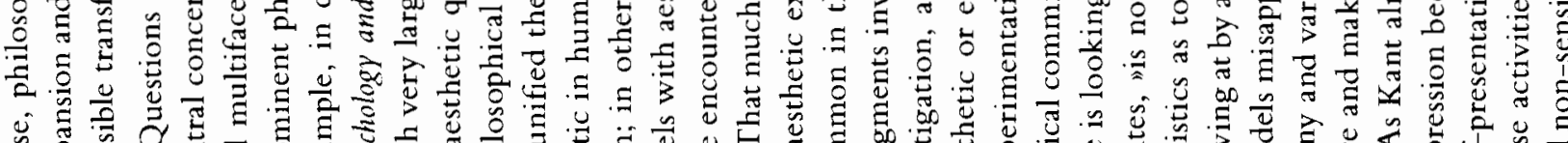

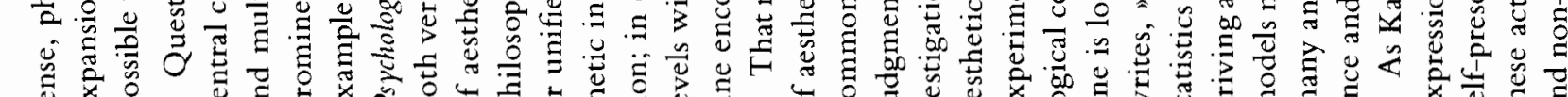

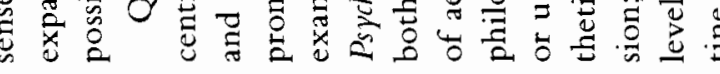




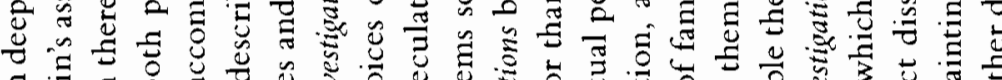

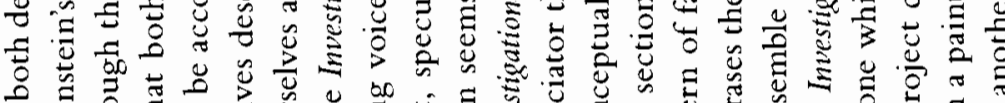

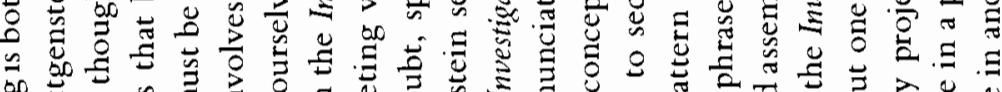

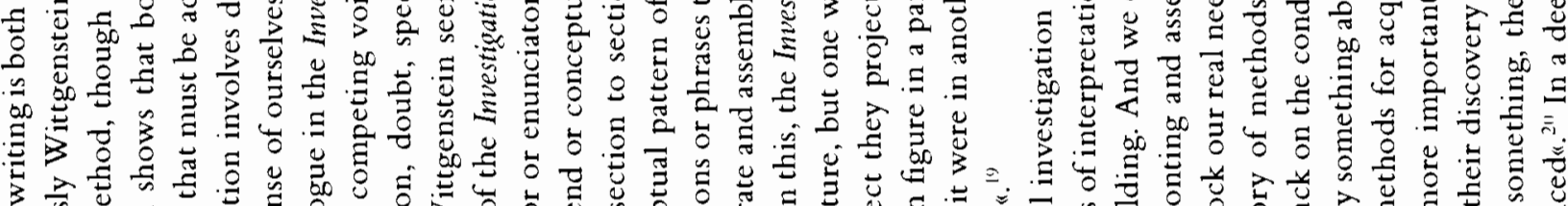

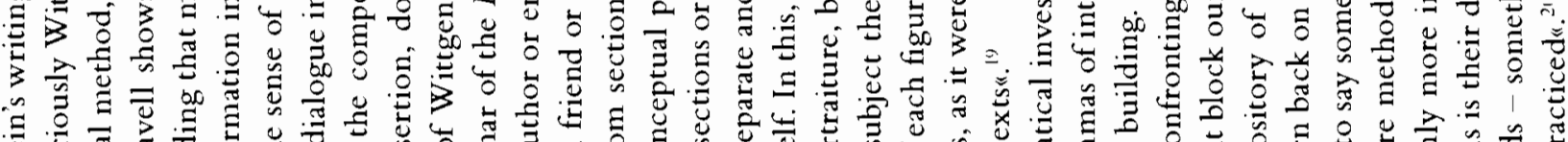

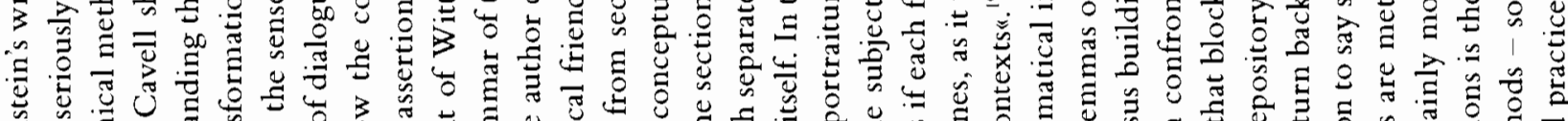

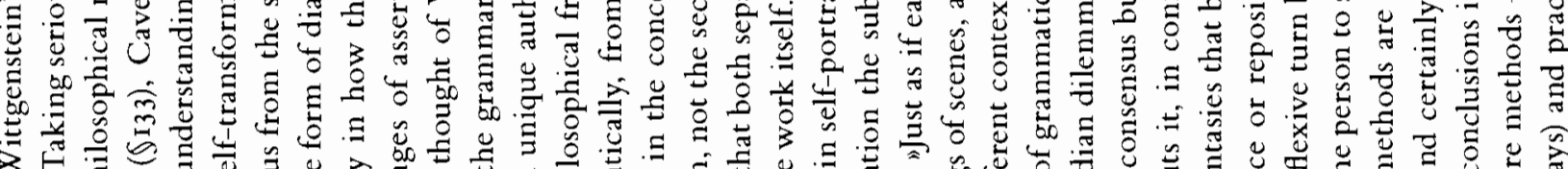

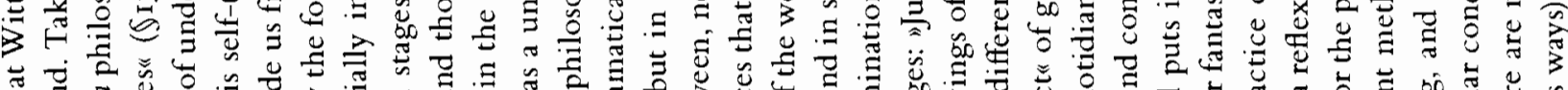

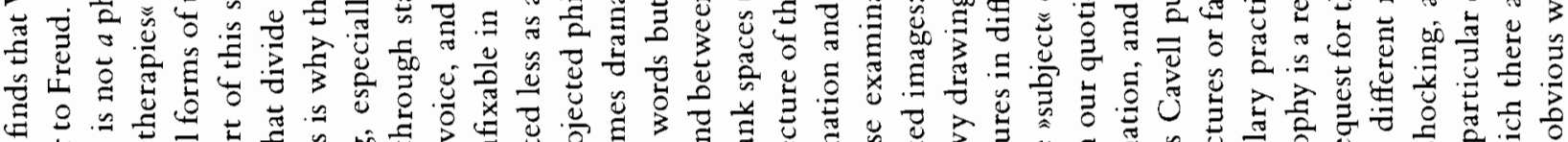

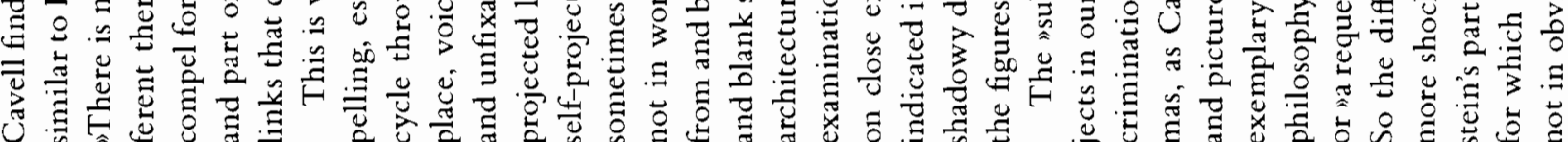

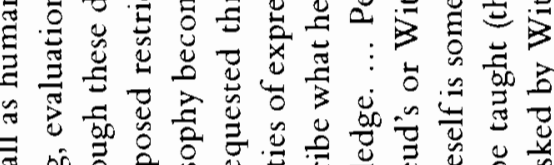

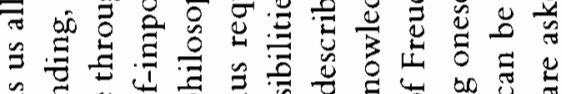

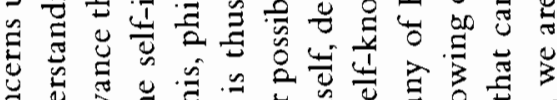

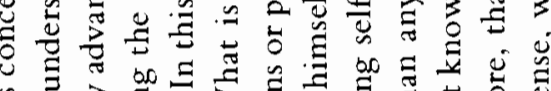

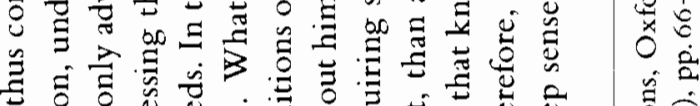

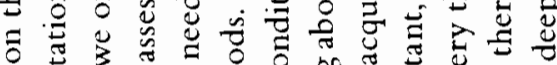

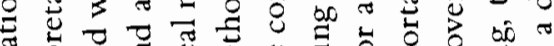

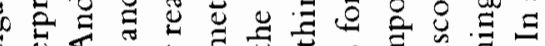
药 즐

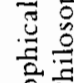
응 을 离 娄

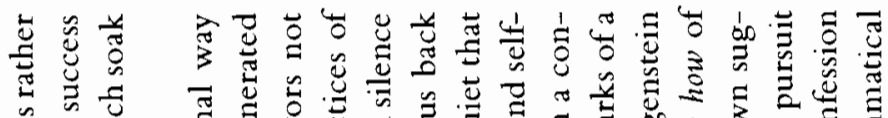

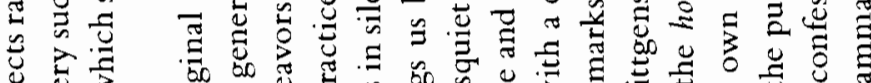

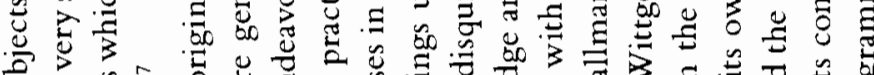

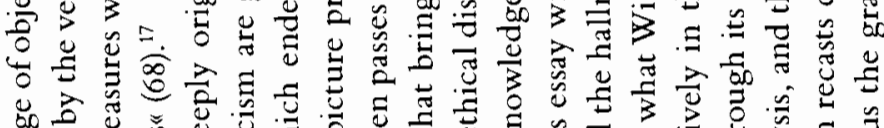

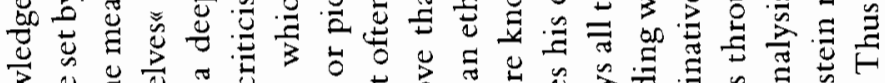

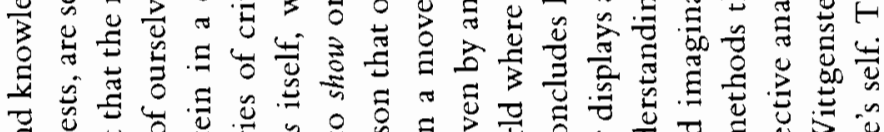
ษ

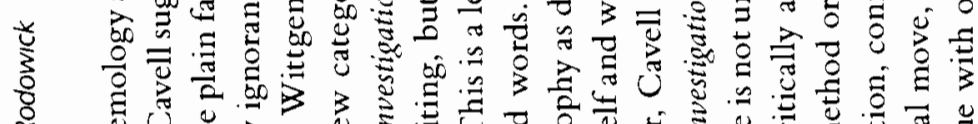

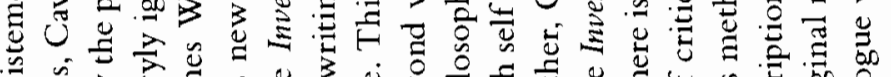

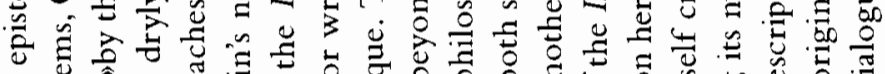

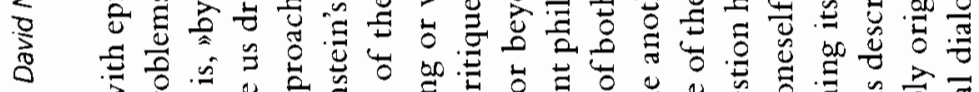

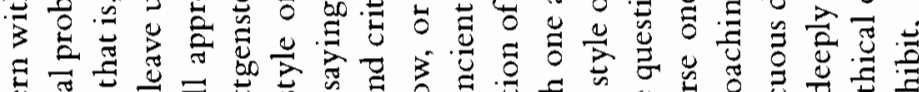

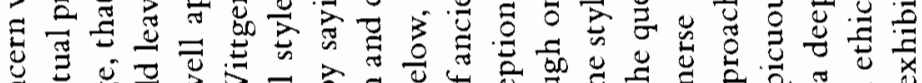

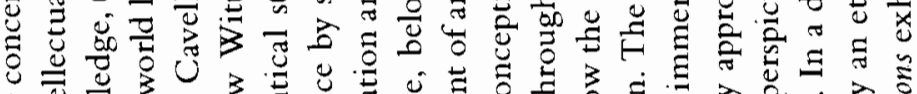

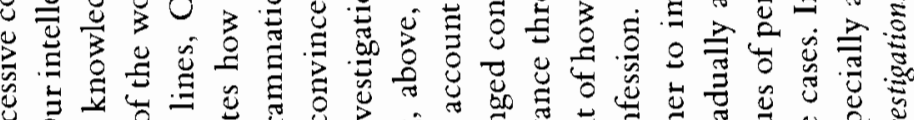

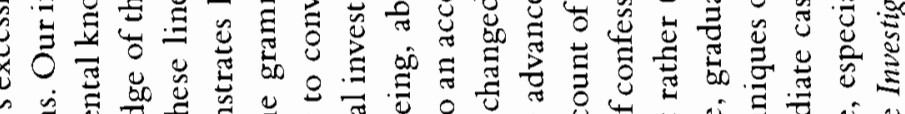

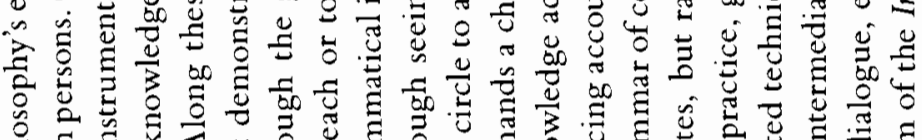

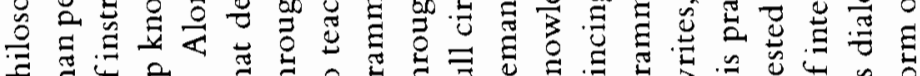

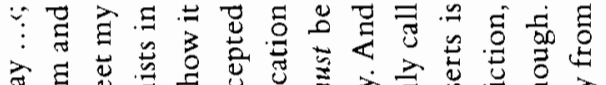

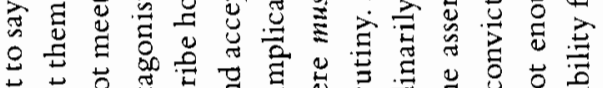

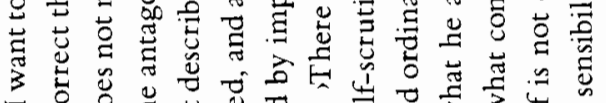

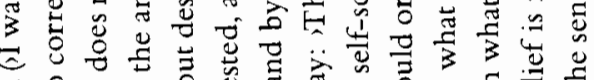

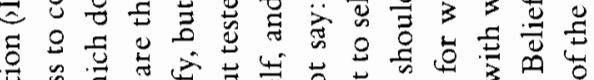

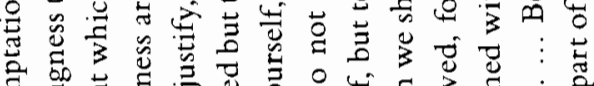

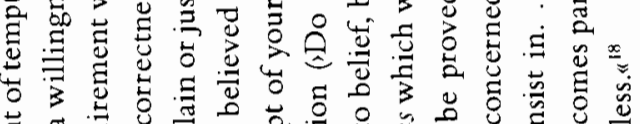

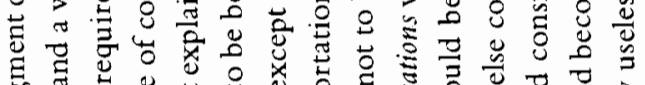

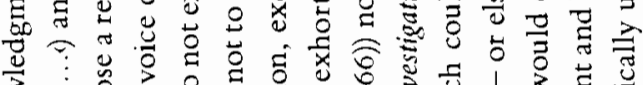

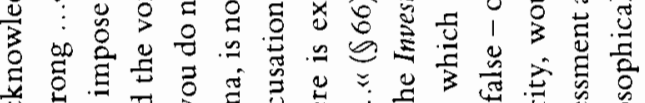

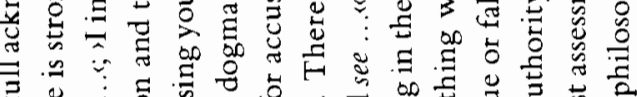
$\bar{\exists}$

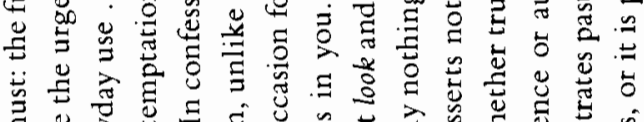

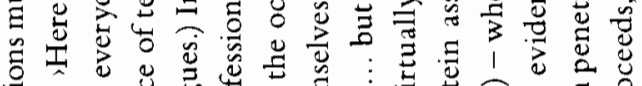

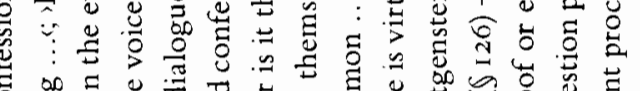

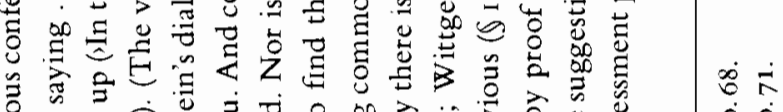

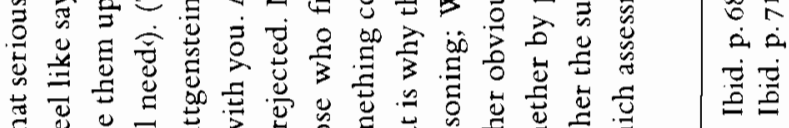

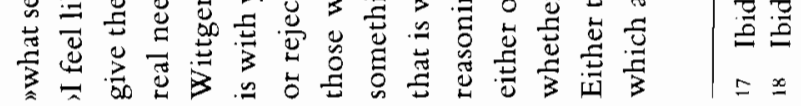




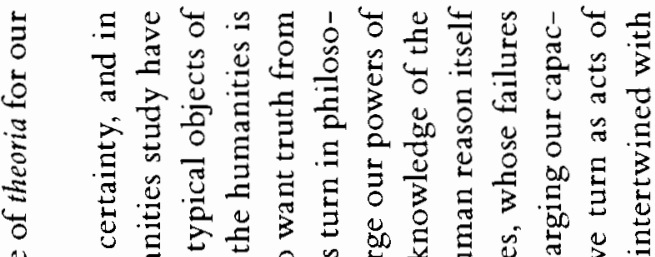

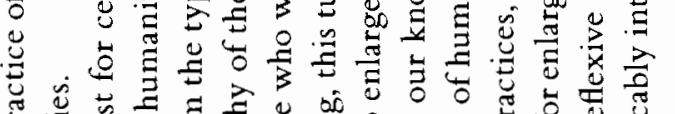

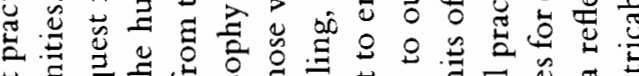

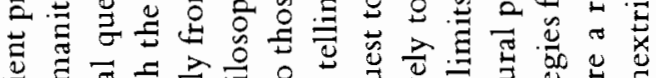

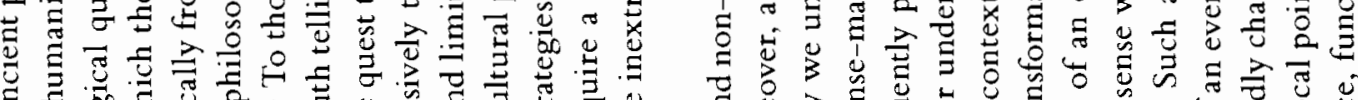
I

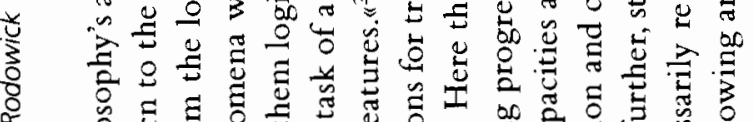

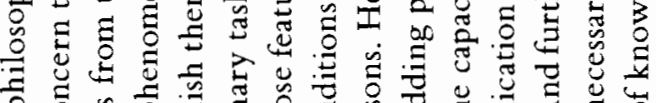

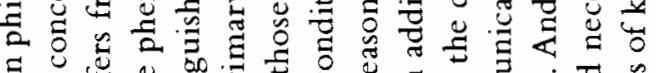

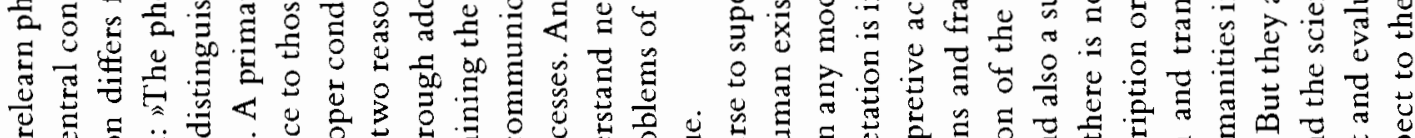

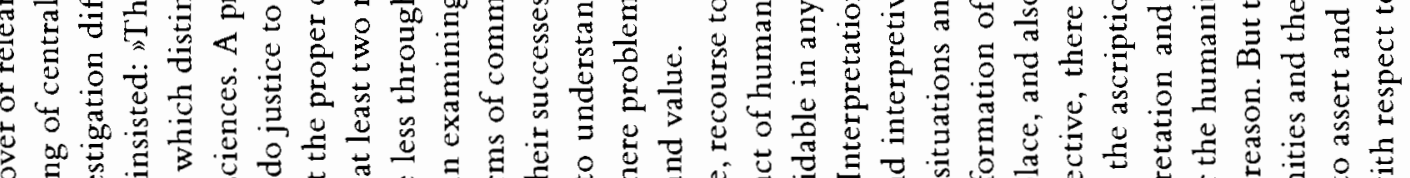

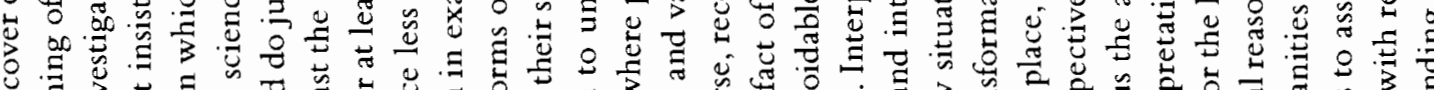

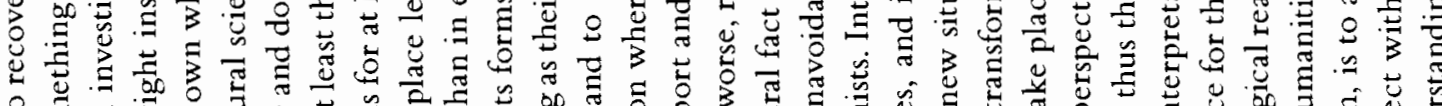

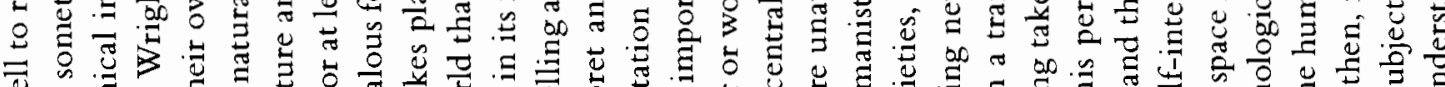

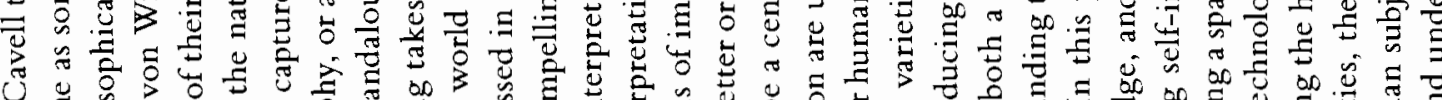

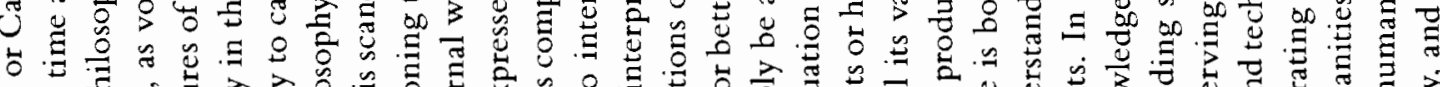

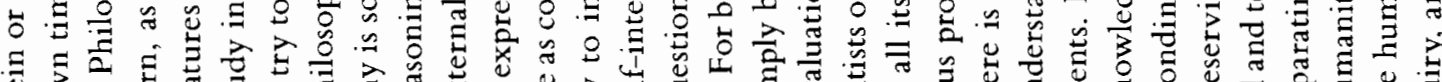

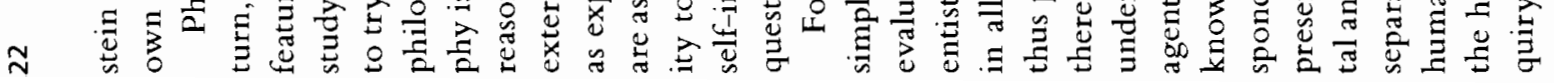

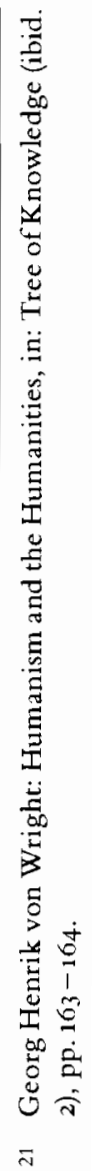

